\title{
Institutional Ownership and the Propagation of Systemic Risk among Banks
}

\begin{abstract}
We investigate whether institutional ownership (IO) plays a role in transmitting systemic risk through banks. We find robust evidence suggesting that IO is positively associated with future systemic risk. We find this relationship is stronger during economic downturns at the economy-wide level, as well as for banks demonstrating greater capital needs. Our results also suggest a trading mechanism through which active, and transient institutions in particular, play a role in propagating systemic risk. We find the relationship exists when there is both overlapping and non-overlapping ownership of banks, and the result is concentrated when there are low monitoring incentives for institutional owners. Furthermore, we find disclosure may play a role in mitigating the transmission of systemic risk by institutional investors. Overall, our results should be of interest to regulators, who have called for institutional investors to play a larger role in bank monitoring, and more broadly to the academic literature that tends to assume the benefits of IO without adequate consideration of the potential costs.
\end{abstract}




\section{Introduction}

This paper examines whether institutional ownership ("IO") acts as a transmission mechanism for systemic risk in the banking sector. Following the financial crisis there was a concerted effort among regulators, academics and practitioners to understand the factors that contributed to the systemic failure of the financial system. An important dimension of systemic risk that was identified is the correlated movements in market prices among banks—i.e., tail-risk contagion - which increased banks' cost of capital and contributed to a liquidity crunch. Initial regulation called for higher capital adequacy requirements, formalized liquidity standards, and periodic stress testing of financial institutions. However, recent reforms have focused on the role of market participants in disciplining and monitoring banks (BIS 2015; Dodd-Frank 2010). This regulatory approach is predicated on the notion that greater disclosures allow sophisticated market participants access to important information relating to a bank's regulatory capital and risk exposures, enabling more effective market discipline. Institutional investors are a key group of market participants that have sufficient sophistication, ability and incentive to engage in monitoring (e.g. Shleifer and Vishny 1986, 1997).

While prior literature has shown that IO may generally serve as an important governance mechanism to mitigate excessive risk taking, the role IO may play with respect to systemic risk in the banking sector is less clear and is the focus of this paper. A considerable amount of academic and practitioner research has been devoted to the study of systemic risk and the factors that influence it. ${ }^{1}$ Prior research suggests systemic risk can arise from external factors such as market

\footnotetext{
${ }^{1}$ For example, prior studies have examined: delayed expected loss recognition (Bushman and Williams 2015), lending concentration of bank portfolios (Beck and De Jonghe 2013), loan diversification practices (Wagner 2010), fair value accounting (Khan, forthcoming), excessive risk taking (e.g. Korinek 2011), and systemic shocks to funding of liquidity providers (Brunnermeier and Pedersen 2009) as factors that have exacerbated systemic risk and financial fragility.
} 
frictions (e.g., illiquidity) due to correlation in tail risk during market downturns or internal factors such as excessive risk taking and correlated credit risk exposure. In this paper, we focus on external factors and argue that institutional investors' sizeable trades, coupled with their correlated funding and trading behavior, may actually serve as a transmission mechanism through which the correlation in tail risk can increase. In turn, this increased tail risk comovement during market downturns can make raising capital more difficult precisely when banks need capital the most, thus, exacerbating systemic risk. Accordingly, we are not advocating that IO creates systemic risk per se, but rather, that it may act as a transmission mechanism through which systemic risk propagates among banks in the financial system.

Our intuition is based on a set of studies that suggests that institutional ownership is associated with excess equity return comovement and a destabilization of prices (e.g. Pindyck and Rotemberg 1993; Boyson, Stahel and Stulz 2010; Della Croce et al. 2011). In our context, IO may exacerbate tail risk co-movement among banks for the following interrelated reasons: First, institutional investors typically hold larger portfolios of stocks than individuals or insiders. The ownership of a portfolio of stocks inherently creates a potential connection between the stocks in the portfolio through the institutional holder (e.g. Anton and Polk 2014). If there is adverse price movement in one of the stocks within the portfolio, the adverse movement has the potential to propagate to the other holdings as the institutional owner responds through rebalancing, i.e. overlapping ownership mechanism (e.g. Kodres and Pritsker 2002). ${ }^{2}$ Second, in down markets, we tend to see more correlated trading among institutions given the adverse funding liquidity shock

\footnotetext{
${ }^{2}$ Whether this rebalancing has an adverse or favorable impact on other stocks in the portfolio is a matter of how the institution specifically rebalances and the potential for increased redemptions. If the adverse price movement results in their offloading of an underperforming sector, it could spread this adverse price movement to other holdings in that sector. If the adverse price movement results in the purchase of more shares in that sector to regain the original percentage holdings in that sector, it could have positive price effects.
} 
to a common pool of capital. For example, Boyson et al. (2010) find evidence suggesting that hedge funds exhibit correlated trading based on correlated factors and adverse liquidity shocks; along the same lines Shleifer and Vishny's (1992) asset fire sale model. Relatedly, correlated returns may occur among a group of stocks due to clientele effects and/or style investing. ${ }^{3}$ Clientele theories assume that each stock has a body of investors who find it attractive, which may lead to only limited market participation in each group of stocks (Sun 2015). Consequently, when a liquidity shock affects a marginal investor, it likely triggers a liquidity shock for the group of stocks in the marginal investor's portfolio. This mechanism simultaneously increases the trading volume and decreases the liquidity of this group of stocks, resulting in excess comovement (see Sun 2015; Greenwood and Thesmar 2011). Finally, program trading and stop-loss mechanisms at asset managers may also contribute to tail risk comovement. ${ }^{4}$ In sum, the degree of IO within banking stocks may be a catalyst for tail-risk comovement and thus propagate systemic risk.

However, we acknowledge arguments to the contrary, i.e., IO may reduce systemic risk. For example, Ye (2012) provides empirical evidence that having more active IO within bank stocks may mitigate excess comovement in stocks, and by extension, should decrease the propagation of systemic risk. Ultimately, this an open empirical question. ${ }^{5}$

\footnotetext{
${ }^{3}$ The style investing refers to the tendency of investors to group assets in categories and then allocate funds on the level of these categories treating all securities within a particular group as indistinguishable. This type of trading behavior could be a result of limited investor attention, specific portfolio objectives, trading restrictions, or regulations. ${ }^{4}$ By "program trading", we refer to the rise in the use of algorithmic trading by IO to buy and sell securities based on predetermined instructions and price movements. This can propagate systemic risk because the trades of these institutional investors will become more correlated precisely when it may have the biggest impact. For example, the influence of these types of mechanisms was evident in the "flash crash" on May 6, 2010. The U.S. equity markets lost close to $\$ 1$ trillion dollars in the space of 36 minutes. The catalyst for the crash was a $\$ 4.1$ billion sell order initiated by a large mutual fund at around 2:32pm, which immediately exhausted the pool of available buyers, sparking further selling by other traders, including HFT algorithms that detected the sell-off and started dumping their positions. The sudden drop in prices also triggered algorithmic stop-losses at several large asset managers, which further depressed prices. The official report by the SEC and CFTC actually referred to this as a "hot potato" effect, highlighting the role of correlated trading.

${ }^{5}$ There is also a body of research that examines the governance role of IO. This may lead to the opposite prediction that higher IO may reduce systemic risk among banks. The intuition is as follows: Institutional investors have incentives to collect information and monitor management because of the sizeable stakes they hold in the firm (e.g.
} 
To test the relationship between IO and systemic risk we take the following empirical approach. We focus on the important dimension of systemic risk that is tail risk co-movement, and examine the co-dependence of equity returns in the left tail of the distribution between a bank and the banking system (e.g. Acharya et al. 2017; Bushman et al. 2016). We take two specific approaches to this measure. Our first proxy is the marginal expected shortfall, which captures the correlation between a bank's equity returns and market equity returns on days where the market return is in the bottom five percent for the year, where the market is defined as the banking sector. Our second proxy for systemic risk captures the extent of this left tail co-dependence by once again computing the distribution of realized returns for each bank and counting the number of overlapping days between individual bank poor performance and poor performance of the banking sector.

Using our two proxies for tail risk co-movement, we regress both measures of tail risk comovement on lagged IO, a set of control variables, and bank and year fixed effects. Consistent with IO behaving as a transmission mechanism, we find that higher levels of prior year institutional ownership are positively associated with banks' tail risk comovement. In addition to there being a statistically significant relationship, our results also suggest the relationship is economically significant. A one standard-deviation increase in institutional ownership is associated with an increase in our tail risk comovement proxies of between 13 and 19 percent relative to sample means. These results are robust to controlling for several other factors related to bank comovement.

Shleifer and Vishny 1986; Gillan and Starks 2003). Higher quality financial reporting can facilitate more effective monitoring by institutions. For example, theoretical and empirical research suggests that institutional investors are attracted to firms with better disclosures due to lower monitoring costs (e.g. Bushee and Noe 2000; Lambert et al. 2007; Ferreira and Matos 2008). Such monitoring by IO can lead to more efficient managerial decisions and outcomes. Accordingly, one may expect IO to be negatively associated with tail-risk co-movement. However, the focus of our paper is on IO exacerbating systemic risk vis-à-vis their trading behavior, to the extent that the monitoring role dominates then we should find opposite results to our predicted positive relation. 
In addition, consistent with IO experiencing common adverse funding liquidity shocks during market downturns, when we partition the sample into periods that capture economic downturns versus expansions we find the positive relation between IO and systemic risk is significantly exacerbated during downturns. Furthermore, we provide strong cross-sectional evidence that IO exacerbates systemic risk within banks with heightened capital needs, consistent with the notion that IO increases tail-risk precisely when banks are most vulnerable.

To provide further evidence that our main results are at least partially attributable to the trading activities of institutional investors, we next examine the relation between tail risk comovement and the ownership of bank stocks by institutions characterized by high turnover. Active managers tend to have more volatile capital flows that could trigger immediate buying and/or selling of portfolio securities. Moreover, large active traders are likely to also engage in algorithmic/program trading which may exacerbate tail risk. In contrast however, Ye (2012) provides novel evidence that suggests that more active IO may actually reduce excess comovement observed in stocks, and find that after active IO exit a stock this results in greater price synchronicity. Extrapolating to our setting, we attempt to answer this open empirical question, and examine whether institutional investors with higher share turnover are more likely to act as a propagator of systemic risk due to the greater number of trades they execute

We employ two measures of "active" IO. First, we isolate high turnover investors based on the turnover of their portfolios during the previous 12-month period using 13F and FactSet portfolio data. Second, we employ the investor classifications of Bushee (2001) who classifies IO as transient, quasi-indexer and dedicated based on size of holdings and portfolio turnover. Using both of these proxies for active trading we find that stock ownership from these "active" investors has a much stronger relation with our tail risk comovement measures. Specifically, the positive 
association between IO and our systemic risk proxies is approximately two to five times stronger for MES and two to four times stronger for the number of overlapping days. Conversely, we find that "dedicated" institutional investors play no role in the transmission of tail risk comovement, but in fact may mitigate the spread of adverse shocks. Overall, this evidence is consistent with arguments that institutional investors' trades can propagate tail risk comovement, with more active institutional owners facilitating greater tail risk comovement, while those with longer-term investment horizons and thus greater incentives to monitor (i.e. "dedicated" investors) may have a stabilizing effect on systemic risk; in-line with the regulatory shift towards market discipline.

Following prior research that suggests stocks with common overlap in IO exhibit excess comovement (e.g. Anton and Polk 2014), we further test the trading mechanism through which IO may propagate systemic risk by directly examining common ownership among banks. Specifically, to test whether overlap in IO contributes to tail risk comovement, we re-define our "bank sector" measure used to compute tail dependence. We match each bank-year observation to other banks that share a common institutional owner and banks that do not share a common institutional owner. We then repeat our main analysis across the two sets of matched bank samples - i.e., those with common overlap and those without- to test whether the overlap in institutional ownership specifically contributes to tail risk comovement. Consistent with the overlapping investor mechanism, we find that banks with shared ownership are four to five times as likely to propagate systemic risk relative to banks that do not share any overlapping institutional investors. However, increased IO still adversely relates to tail risk comovement among banks without any common overlap in IO, consistent with investor clientele and style investing theories, and algorithmic-trading programs of large asset managers. These results also support the idea that 
an overlapping active investor base is not the only mechanism through which IO can influence tail risk co-movement.

As prior literature suggests IO may play a governance role by monitoring firm activities to increase firm value, we next partition our results based on the concentration of institutional owners as a proxy for the strength of monitoring incentives. Specifically, if institutions that trade more propagate tail-risk comovement, we would expect institutions with less monitoring incentives to drive this result versus the institutions that monitor and are more likely to trade based on fundamentals. We compute the concentration of IO holdings for banks in our sample using the Hirschman-Herfindahl Index and partition our sample into dispersed and concentrated IO, representing low and high monitoring incentives, respectively. We find that the positive association between IO and tail risk comovement documented is driven by the more dispersed IO subsample (i.e. low monitoring incentives), while in the more concentrated IO subsample (i.e. high monitoring incentives), IO has no detectable relation with systemic risk. These results are consistent with the notion that once many institutional owners purchase a stock, dispersed ownership reduces the individual incentive to monitor and leads to free-rider problems (i.e. each investor relies on others to undertake costly monitoring activities). Moreover, given the large number of stocks institutional investors tend to hold and their relatively short-term orientation, there is less incentive for them to monitor individual firms, since they will simply "exit" their positions at the first sign of poor performance (e.g. Manconi et al. 2012).

After exploring whether IO is positively associated with tail risk comovement, we turn to whether disclosure can mitigate the adverse effects of institutional trading by decreasing information asymmetry and increasing stock liquidity. Basel III is based on the principle that increased disclosure allows market participants to better monitor the risks a bank undertakes (BIS 
2015). To this end, a growing literature in accounting suggests that higher quality disclosures can mitigate systemic concerns (Bushman and Williams 2015). Moreover, as institutions experience adverse shocks in their portfolios, greater disclosure may reduce the uncertainty surrounding the fundamentals of the bank, reducing the propagation of the adverse shock for banks who are more transparent (e.g. Brunnermeier and Pedersen 2009). Accordingly, we posit that greater bank disclosures will help reduce uncertainty regarding the bank's underlying economic activities and may decrease both the correlation across institutional investors' trades as well as the correlation of trades within an institution's portfolio. Consistent with these arguments we find that the relation between IO and systemic risk is primarily isolated within those banks with low disclosure. This provides initial evidence that greater disclosures may mitigate, but not completely offset, the relationship between IO and tail risk comovement.

A concern that may arise in examining the relation between IO and tail risk co-movement is that institutional owners may have a preference for certain types of banks, particularly banks that have a high contribution to systemic risk. While it is not clear to us ex ante why IO would have a preference for high tail risk co-movement stocks, we still try to empirically address this endogeneity concern using an instrumental variables approach to provide further support for our initial results. Specifically, we use the Russell 1000 index classifications as our instrument. We examine banks within the lower bound of the Russell 1000 index and the upper bound of the Russell 2000 index, we attempt to isolate the exogenous variation in IO. Upon re-estimating our analyses, we find consistent results with our main findings: higher IO is significantly associated with greater future systemic risk.

Overall, our results suggest that IO could be a transmission mechanism of systemic risk through tail risk comovement, highlighting the importance of the nuanced benefits and potential 
costs of current regulatory discussions suggesting that greater disclosure will encourage better monitoring from sophisticated investors. That is, the same investors that will be attracted by greater disclosures and can monitor well, may also exacerbate tail risk comovement due to the nature of their trading.

This paper primarily contributes to the literature on systemic risk. While prior research has explored various determinants of a bank's susceptibility to systemic risk, to our knowledge, our paper is the first to investigate whether a bank's investor base is one of the mechanisms that facilitates systemic risk. Understanding the role of IO in transmitting systemic risk through tail risk comovement is important, as regulators have called for increased disclosure quality to increase public monitoring of banks in hopes to reduce systemic risk. While institutional investors are arguably well equipped to monitor bank behavior, the nature of the institutional holdings creates a network to transmit systemic shocks from one bank to the other. Our results provide a mechanism, the trading behavior of institutional ownership, through which financial markets themselves can trigger and transmit systemic risk. Moreover, we also highlight that the type of IO has differential impacts on the propagation of systemic risk among banks. ${ }^{6}$

Relatedly, our results should also be of interest to regulators given the potential for IO to be a transmission mechanism for tail-risk comovement. This is especially true given the focus of the recent Basel III on market discipline, and the recent call from the Financial Stability Oversight

\footnotetext{
${ }^{6}$ A concurrent working paper by Iselin et al. (2017) also examines the impact of institutional ownership on systemic risk; however, Iselin et al (2017) focus exclusively on the contribution of overlapping block ownership - i.e. greater than $5 \%$ ownership of equity. Their study differs from ours on several important dimensions. First, we examine institutional ownership more broadly, i.e. total institutional ownership within banking stocks as opposed to only overlapping ownership by block holders. Second, we examine whether characteristics of IO play different roles in contributing or mitigating systemic risk. Third, we also examine the role of disclosure in mitigating or attenuating the relation between IO and systemic risk. Finally, the choice of systemic risk proxies and research design choices differ somewhat between the two papers.
} 
Council (FSOC) for research to understand the channels through which the asset management industry could transmit risks across financial markets, and whether to consider large institutional investors for enhanced prudential standards and supervision under Dodd-Frank. Our findings suggest that more active and transient IO propagate systemic risk. Therefore, while IO may be able to act as a governance mechanism and promote private monitoring this needs to be weighed against the possibility that institutional ownership acts as a transmission mechanism for industry shocks.

Finally, we also contribute to the literatures on disclosure and the role of institutional investors by investigating a potential cost of increased institutional ownership. Institutional funds are important in the economy as they help investors diversify their assets and provide financing to firms. Papers on disclosure and investor relations usually assume, either explicitly or implicitly, that increased institutional ownership is a desirable outcome for firms (e.g., Bushee and Miller 2012; Kirk and Vincent 2014). Our results suggest that institutional ownership can be costly for firms in the financial sector by transmitting systemic risk. This evidence resonates with the IMF's concerns about investment funds posing financial stability risks (International Monetary Fund 2015).

\section{Data, Variable Measurement, and Descriptive Statistics}

\subsection{Data}

We obtain data from several sources: institutional holdings data is obtained from FactSet/LionShares, financial data from the Compustat Bank Fundamentals file, and market data (e.g. returns, prices, market capitalization and volume) from CRSP. Our final sample is the intersection of all three data sources, matched on CUSIP. We begin our sampling procedures by taking all banks from the Compustat Bank Fundamentals file incorporated in the U.S. with a 
December fiscal year-end and at least one-year of return data within our sample period of 20012013, effectively capturing all depositary institutions trading on US stock exchanges. Our sample begins in 2001 to ensure the entire sampling period is consistent with post-Glass Steagall repeal regime. This leaves us with a sample of 7,621 bank-years for 1,019 unique firms. We then merge in institutional investor holdings data from FactSet/LionShares. In less than six percent of firmyears where no institutional holdings can be found we assume holdings of zero. We then compute

our systemic risk measures using market data and control variables using both Compustat and CRSP. Given we require a constant sample for our main analyses; we require all bank-year observations to have sufficient data. Our final sample consists of 6,493 bank-years (937 banks) from 2001 to 2013.

\subsection{Measuring Systemic Risk}

Given we are interested in the relation between IO and systemic risk, the empirical approach to measuring systemic risk is an important consideration. At a broad level, systemic risk can refer to any set of circumstances that threatens the stability or public confidence in the financial system and impairs its functioning (e.g., Billio et al. 2011; ECB 2010). However, there is a lack of consensus among policymakers, regulators or academics as to how to precisely define or measure systemic risk (see Bisias et al. 2012 for review). Measures of systemic risk vary from countrylevel outcomes (e.g., asset price boom/bust cycles, credit gap indicators, and GDP stress tests), to firm-level outcomes focused on codependence of market outcomes (e.g., marginal expected and systemic shortfall, CoVAR, and serial correlation and liquidity in hedge-fund returns).

An important dimension of systemic risk is tail risk comovement and, as such, we appeal to a stream of literature that focuses on codependence in the tails of equity returns. This dimension is intuitively appealing given that tail risk reflects the market's risk assessment of the bank (and 
banking system) based on a broad set of factors and vulnerabilities (e.g. Acharya et al. 2017; Adrian and Brunnermeier 2009; Bushman and Williams 2015; De Jonghe 2010). The growing popularity of market-based measures of bank risk from regulators and academics alike is based on empirical evidence that market signals contain pertinent information about banks' risks. ${ }^{7}$ By focusing on banks' exposure to market crashes, this measure incorporates a systemically relevant consequence, given many banks get into distress at the same time when the economy contracts severely (e.g., Knaup and Wagner 2012). For regulators, having an estimate of how much an individual bank is exposed to a banking sector crash (i.e. tail risk) is important as it can help to identify potentially weak banks and it may help to further understand determinants of systemic risk (Bisias et al. 2012). Moreover, given our focus on the role of institutional ownership on the propagation of systemic risk, tail risk measures have a natural link to trading behavior of market participants. Our focus on the role of IO in the propagation of systemic risk is also in line with recent calls from the Financial Stability Oversight Council (FSOC) to study the activities of asset managers to better inform whether-and how - to consider large institutional investors for enhanced prudential standards and supervision under Dodd-Frank (FSOC 2012). Guided by the FSOC mandate, the Office of Financial Research has undertaken several studies to better understand the channels through which the asset management industry could transmit risks across financial markets (e.g., OFR 2013). For all the aforementioned reasons, we examine whether IO may propagate systemic risk vis-à-vis tail-risk contagion.

We employ two proxies to measure systemic risk that are adapted from the Marginal Expected Shortfall measure of Acharya et al. (2017). This measure captures the connection between a bank's equity returns and the banking sector ("market") equity returns on days when

\footnotetext{
${ }^{7}$ For a survey of the empirical evidence see Flannery (2001) and Bisias et al. (2012).
} 
the market return is in the bottom $5 \%$ for the year. Accordingly, our first measure, $(M E S)$, is defined as the average return of a bank $\left(R_{i}\right)$ during the bottom $5 \%$ of return days for the overall banking sector $\left(R_{m-i}\right)$ for a given calendar year $t$. The banking sector return $\left(R_{m-i}\right)$ is defined as the daily value-weighted return of all sample banks, excluding bank $i$. This measure captures the extent to which an individual bank performs poorly when the sector as a whole is performing poorly, i.e. its losses in the tail of the aggregate sector's loss distribution.

Our second measure, Overlap_Low_Days, reflects the number of days in year $t$ that both bank $i$ and the overall banking sector simultaneously experience poor return performance. We define this variable as the number of days in year $t$ that bank $i$ 's bottom twenty days of daily stock returns coincide with the bottom twenty days of the value-weighted banking sector return $\left(R_{m-i}\right) .{ }^{8}$ This measure can vary between 0 days (no overlapping days) and 20 days (perfect overlap).

We report descriptive statistics relating to our two systemic risk variables in Table 1 . We note mean values of MES and Overlap_Low_Days of -0.0115 and 5.1314, respectively. As expected, $M E S$ is negative $1.1 \%$, with the average bank having approximately five of their worst return days overlapping with poor overall sector performance. Overlap_Low_Days varies from 2 at the $25^{\text {th }}$ percentile to 8 at the $75^{\text {th }}$ percentile, while MES remains negative and varies from $-1.9 \%$ at the $25^{\text {th }}$ percentile to $-0.12 \%$ at the $75^{\text {th }}$ percentile. Furthermore, the correlation between our two measures of systemic risk is -0.70 , providing further evidence consist with our proxies capturing a similar construct.

\subsection{Measuring Institutional Ownership}

We obtain institutional holdings data from FactSet/LionShares, which contains both 13F holdings and global mutual fund holdings disclosures. The Securities and Exchange Commission

\footnotetext{
${ }^{8}$ For both measures, we exclude firm-years that do not have a full year of returns data in CRSP.
} 
(SEC) requires all institutions, including foreign investors, that have investment discretion over $\$ 100$ million or more in Section 13(f) securities (i.e. publicly traded equity, convertible bonds, and some options) to disclose their quarter-end holdings in these qualifying assets on Form 13F. This ensures we are getting a complete picture of large institutional ownership of our sample banks. However, institutions that hold fewer than 10,000 shares in a given stock and have aggregate fair market value of holdings in that stock totaling less than $\$ 200,000$ may omit these smaller holdings. In order to capture some of these smaller positions, we augment our 13F data with global mutual fund holdings data obtained from FactSet/LionShares to create a comprehensive dataset of institutional holdings. We sum the holdings of all institutions in a given bank's stock at the end of each calendar year and divide it by the total number of shares outstanding. Our primary variable of interest, $I O$, is the fraction of total shares outstanding at the end of the calendar year held by institutional investors. As reported in Table 1 our sample banks have an average of $26 \%$ institutional ownership.

We also breakdown IO into "active" and "passive" based on the extent of portfolio turnover within each year. Specifically, we define active institutional owners based on portfolio turnover classifications provided by FactSet, where those institutions classified as having "Very High" and "High" portfolio turnover are "active." We merge our holdings data to our sample of banks using CUSIP. In addition, we also employ the investor classifications of Bushee (2001) to classify IO as dedicated, quasi-indexer and transient based on their holdings turnover. Where transient investors are "active" IO, and dedicated IO are those institutions with large long-term positions and likely have a greater monitoring role. 


\section{Research Design}

To examine the relation between systemic risk and institutional ownership, we estimate the following OLS regression:

$$
\begin{aligned}
\text { SYS }_{-} \text {IISK }_{i, t}= & \beta_{0}+\beta_{1} \text { IO }_{i, t-1}+\beta_{2} \text { Size }_{i, t-1}+\beta_{3} \text { Beta }_{i, t-1}+\beta_{4} \text { Opacity }_{i, t-1}+\beta_{5} \text { Tier }_{i, t-1} \\
& +\beta_{6} \text { Deposits }_{i, t-1}+\beta_{7} \text { Revenue Mix }_{i, t-1}+\beta_{8} \text { Stock Vol }_{i, t-1}+\sum \text { Bank FE } \\
& +\sum \text { Year FE }+\varepsilon_{i t}
\end{aligned}
$$

where SYS_RISK is either MES or Overlap_Low_Days. We control for bank size, beta, opacity, Tier 1 capital, deposits, revenue mix, stock volatility, as well as bank- and year-fixed effects. Systemic risk measures are defined in section 2.2. Size is calculated as the log of total assets as of the end of the year and controls for the fact that larger banks will have a higher association with systemic risk. Beta is the correlation between the annual value-weighted market return, excluding the firm of interest, and the firm return. Given several prior studies have documented IO and comovement in returns, including beta in our empirical specifications effectively controls for the correlation in returns across the entire return distribution, allowing us to isolate the incremental tail-risk. Opacity is measured as the amount of derivative liabilities scaled by total assets at the end of the prior year. The amount of derivative liabilities is calculated as the sum of the gross amount of derivate liabilities from trading activities and that from nontrading (i.e., hedging) activities. We include this variable to control for previously documented relation between IO and opaqueness. Tier 1 is the Tier 1 risk-adjusted capital ratio of the bank at the end of the prior year, controlling for bank capital. Deposits, measured as total deposits scaled by total liabilities at the end of the prior year, assists us in controlling for differences in funding stability. We also control for Revenue Mix, which is measured as interest revenues divided by total 
revenues at the end of the prior year. Lastly, we control for Stock Volatility computed as the standard deviation of the bank's daily stock returns over the prior year, to control for idiosyncratic risk. We also include bank and year fixed effects, and cluster standard errors at the bank-level to control for transitory shocks correlated across time for a given bank. All variables are defined in further detail in Appendix 1.

\section{Empirical Results}

\subsection{Institutional Ownership and Systemic Risk}

Table 2 presents the multivariate regression results examining the base relation between IO and systemic risk. There is a negative coefficient on $I O$ when $M E S$ is the dependent variable (model 1) and a positive coefficient on $I O$ when Overlap_Low_Days is the dependent variable (model 2). Both coefficients are statistically significant at the $1 \%$ levels. Consistent with our primary hypothesis, the evidence suggests that higher levels of institutional ownership are significantly associated with higher future systemic risk, both in terms of lower average returns on the lowest market return days and a higher number of overlapping days with the lowest market return days. The results are also economically significant, with a one standard deviation increase in institutional ownership is associated with a decrease (increase) in MES (Overlap_Low_Days) of $19 \%(13 \%)$, relative to sample means. ${ }^{9}$

The coefficient estimates for the control variables also indicate that tail risk comovement, as represented by our proxies, increases with the size of a firm, and the correlation with the annual value-weighted market return, consistent with our understanding and prior literature.

\footnotetext{
${ }^{9}$ We also run a "changes" specification, where we regress year-on-year changes in our systemic risk proxies on exante chances in IO and find similar results. In particular, we find a negative and significant coefficient on $\triangle M E S$ of 0.007 (standard error of 0.003) and positive and significant coefficient on AOverlap_Low_Days of 2.978 (standard error of 0.578 ). This provides further corroborating evidence linking IO to systemic risk.
} 


\subsection{Institutional Ownership and Systemic Risk in Economic Downturns}

While the prior results present initial evidence that IO is related to future systemic risk, we would expect this relation to be stronger during economic downturns if IO is a potential transmission mechanism of systemic risk. During economic downturns, banks are more likely to need to raise capital while simultaneously facing illiquid markets (Bushman and Williams, 2015). Furthermore, the presence of institutions in the shareholder base of banks likely magnifies the illiquidity concerns because during these down markets, institutional investors are likely to face shocks in their own portfolio, adverse shocks to their funding liquidity, and their trades are likely to be more correlated (e.g. Boyson et al. 2010).

To test our conjecture, we estimate equation (2) during economic downturns ("recession" and "high private debt to GDP" periods) and in all other periods outside the economic downturns ("expansion" and "low private debt to GDP periods"). A bank-year is defined as a "recession" year if the majority of the calendar year is comprised of recessionary periods. ${ }^{10}$ A bank-year is defined as a "high private debt to GDP" if the U.S. private debt to GDP is higher than the sample median. We use the high private debt to GDP ratio as an additional proxy for economic downturns as the Bank for International Settlements (BIS) has regularly published and monitored countrylevel aggregate private sector credit-to-GDP gaps as an early warning indicator (EWI) of banking crises in an attempt to detect the build-up of financial booms. The basic intuition is that outsized financial booms can generate the conditions for future banking distress and can be represented by surges in private debt.

We present the results in Table 3 . Using the recessionary periods designated by the NBER as our measure of economic downturns in Panel A, we see that across both the recession and

\footnotetext{
${ }^{10}$ As per the National Bureau of Economic Research (NBER) business cycle dating.
} 
expansion partitions the coefficient on IO is negative for $M E S,{ }^{11}$ while they are positive and significant for Overlap_Low_Days. While the coefficients are not statistically different, the magnitude of the coefficients are consistent with our arguments. Specifically the economic magnitude of the recession coefficient in the Overlap_Low_Days regression suggests that a one standard deviation increase in IO leads to an $18 \%$ increase in the bank's overlap when the sector is experiencing low returns. In contrast during expansion periods the economic magnitude drops to approximately $11 \%$.

Panel B presents the results for the partitions of bank-years according to national aggregate levels of private debt to GDP. We see that across both the low and high partitions the coefficient on IO is negative for $M E S$, while they are positive and significant for Overlap_Low_Days. The magnitude of the coefficients are consistent with our arguments and statistically different at $1 \%$ for Overlap_Low_Days. Specifically the economic magnitude of the high private debt to GDP coefficient in the Overlap_Low_Days regression suggests that a one standard deviation increase in IO leads to a $21 \%$ increase in the bank's overlap when the sector is experiencing low returns. In contrast during expansion periods the economic magnitude drops to approximately $8 \%$.

Overall, the results are consistent with IO acting as a potential channel through which systemic risk can propagate through the banking sector, with the relationship appearing to be stronger during economic downturns as we would expect. In the following sections, we set out to validate our systemic risk proxies and better understand the underlying mechanisms through which IO may act as a transmission mechanism.

\footnotetext{
${ }^{11}$ Although larger in magnitude, the coefficient is not significant for the recession subsample possibly due to the smaller sample size.
} 


\subsection{Institutional Ownership, Systemic Risk and Capital Needs}

The positive relation between IO and our systemic risk proxies can be particularly damaging to the banking system during periods in which banks have higher capital and liquidity needs. One of the reasons tail-risk comovement is seen as an important dimension of systemic risk is because the correlated drops in banking sector prices make it difficult for banks to raise equity and keep adequate capital and liquidity ratios during periods when they need it the most. Thus, as the previous results suggest IO may exacerbate equity price tail risk, we would expect the association between IO and our systemic risk measures to be stronger for banks with higher capital needs. To test this prediction, we partition our sample into high and low capital need bank-years, using both bank capital ratios and their liquid asset shortfall.

Table 4, panel A presents the results for the partitions on low and high capital ratios. Low Capital Ratio equals one when the Combined Risk-Adjusted Capital Ratio for the bank is below 13\%. High Capital Ratio equals one when the Combined Risk-Adjusted Capital Ratio for the bank is above 20\% (Bushman and Williams, 2012).

Our motivation is that when banks are closer to capital ratio regulatory thresholds it may indicates a need to raise additional capital soon. Consequently, a lower capital ratio suggests a potential position of greater capital needs. Consistent with our hypothesis, we find that the association between IO and our measures of systemic risk is only significant when banks exhibit lower capital ratios. This aligns with the idea that IO may increase the tail-risk of banks precisely when they are most susceptible to this propagation of systemic risk, specifically when they have greater capital needs.

The liquidity coverage ratio (LCR) of Basel III imposes that financial firms hold a sufficient amount of high-quality liquid assets to cover their liquidity needs over a month of stressed liquidity 
scenario. We follow Pierret (2015) and use a measure of liquid asset shortfall to proxy for regulators' liquidity coverage ratio. Our liquid asset shortfall measures the difference between a bank's short-term debt and short-term assets and is used in this paper as a proxy for the exposure of a bank to funding liquidity risk. The higher a bank's liquid asset shortfall, the greater its funding risk is. The complete description of the computation of our Liquid Asset Shortfall measure is in Appendix 1.

To investigate whether our results on the association between IO and systemic risk are stronger for banks with higher funding risk, which would be particularly concerning for regulators, we partition our sample into banks with high and low liquid asset shortfall. Specifically, we examine the bank-years in the top and bottom terciles of our measure of liquid asset shortfall to compare the banks that are more and least likely, respectively, to be subject to the propagation of systemic risk through IO based on their capital needs. Table 4, panel B presents the results. Consistent with the results in panel A, it is only in the subsample of high capital needs bank-years, in this case high liquid asset shortfall bank-years, that the coefficient on IO is statistically significant across both measures of systemic risk.

These findings may be of particular interest and relevance to regulators as it suggests that banks with higher levels of IO may have difficulties in maintaining their capital adequacy and covering their debt with liquid assets.

\subsection{Type of Institutional Ownership}

While our initial results suggest that IO could be a mechanism through which systemic risk propagates through the banking sector, we turn our attention towards specific types of institutional investors to give more credence to the trading mechanism we suggest in this paper. Specifically, we hypothesize that active institutions, where active is defined as high turnover funds, and 
transient investors, where transient is defined as in Bushee (2001) as institutions with short investment horizons, should have a stronger relation to our systemic risk measures due to the fact that these funds trade more, are likely to have more correlated demand within the banking sector, and thus are more likely to propagate comovement (e.g. Greenwood and Thesmar [2011]).

When isolating active funds in Table 5 panel A, we find that the coefficients are still in the predicted directions and have similar significances to our original pooled results, but importantly the coefficient magnitudes are much larger for active institutions. For $M E S$, the coefficient on $I O$ is more than five times greater in magnitude than the original coefficient in Table 2, while for Overlap_Low_Days, the coefficient increases almost four-fold, however it should be noted that the average active IO within banks is a relatively small portion of the total IO. These results add strength to the argument that institutions are the mechanism through which systemic risk propagates through the banking sector and that active institutions in particular contribute to this risk through their trading behavior.

In addition, we also employ the investor classifications of Bushee (2001) and run our main specifications for transient, quasi-indexer, and dedicated IO. Table 5, Panel B reports our results. Consistent with our results on active IO, we find a negative and significant coefficient on transient IO that is almost three times larger than our main results in Table 2 for $M E S$ and a significantly positive coefficient on transient IO that is more than two times larger than its analog in Table 2 for Overlap_Low_Days. In contrast, we find a positive (negative) but insignificant coefficient on dedicated IO for MES (Overlap_Low_Days), possibly suggesting these institutional investors may in fact attenuate the propagation of systemic risk, consistent with the greater monitoring role these particular type of institutions may play. 


\subsection{Common Institutional Ownership}

To further examine the trading mechanism we propose, we examine a specific channel through which IO may propagate systemic risk, overlap in IO. To this end, we match each bankyear observation to other banks that share a common institutional owner and banks that do not share a common institutional owner. We then repeat our main analysis across the two sets of matched bank samples to test whether the overlap in institutional ownership specifically contributes to systemic risk. More specifically, we re-define banking sector to include only those banks that share institutional investors, i.e. have overlapping IO.

Table 6 presents the results. Consistent with our predictions, we find that overlapping IO is significantly more likely to propagate systemic risk, relative to non-overlapping IO, providing a direct channel through which IO can transmit systemic risk. Specifically, the adverse effect of IO on systemic risk is almost five times stronger for $M E S$ and four times stronger for Overlap_Low_Days for shared ownership. ${ }^{12}$ However, it is important to note that even in the absence of an overlapping IO investor base, we find that IO is still able to exacerbate tail risk comovement. This evidence is consistent with theories of investor clienteles (e.g. correlated style investing) that predict comovement in market prices without necessarily requiring overlapping investor base, as long as investor preferences are correlated within a clientele (e.g. Barberis and Shleifer 2003; Sun 2015). For example, several hedge funds pursuing the same investment style, e.g. value or momentum, will tend trade in the same set of stocks. Moreover, as these investors' risk aversion, sentiment, or liquidity needs change they alter their exposure to the preferred set of stocks which in turn leads to correlated trading patterns (e.g. Sun 2015; Greenwood and Thesmar 2011). Consistent with these arguments our results suggest that correlated demand and the large

\footnotetext{
${ }^{12}$ These results are broadly consistent with a concurrent working paper by Iselin et al. (2017) who document that overlapping block ownership - i.e. equity stakes greater than $5 \%$ - exacerbates systemic risk.
} 
positions of institutional investors within the banking sector alone is enough to significantly increase tail risk co-dependence.

\subsection{Institutional Ownership Dispersion}

Motivated by the recent push from the Basel III requirements to strengthen market discipline, we examine whether variation in the monitoring incentives of institutional owners matters for the relationship between IO and tail risk comovement. Specifically, if an institution has an incentive to monitor, it could play this market disciplining role. However, if IO is acting through a trading channel as we propose, we would expect institutions that have less of an incentive to monitor to drive our initial results as these firms are more likely to simply exit their poor performing positions.

We begin by computing the concentration of IO holdings for the banks in our sample using the Hirschman-Herfindahl Index, normalized to be between zero and one. IO is considered dispersed (concentrated) when the Hirschman-Herfindahl Index is below (above) the sample median. In examining IO concentration we expect the observed relation between IO and systemic tail risk comovement is likely to be driven by those banks with more dispersed IO. We posit this

for the following reasons: (1) the incentive to monitor is reduced with more dispersed IO due to free-rider problems, i.e. each investor relies on others to undertake the costly activity of monitoring; and (2) the relative ease of "exit" for any given institution given their larger more diversified portfolios.

Table 7 reports results from our main specification partitions based on the dispersed and concentrated IO. For the subset of banks with dispersed IO we find a significantly negative coefficient (-0.010) on $I O$ in our $M E S$ specification, and a significantly positive coefficient (3.199) on $I O$ in our Overlap_Low_Days specification. In contrast, the coefficients on $I O$ for both our 
systemic risk measures for the subset of banks with more concentrated IO are much smaller in magnitude and furthermore, not statistically significant. Taken together, these results suggest that particularly when many institutional owners enter a stock and IO becomes more dispersed this reduces the individual incentive to monitor and IO can exacerbate systemic risk. These results are also broadly consistent with our empirical findings in Table 5 where we observe transient IO exacerbates tail risk comovement.

\subsection{Institutional Ownership, Systemic Risk and Disclosure}

Given the regulatory approach of Basel III to promote market discipline in part through greater disclosures, we next examine the role disclosure plays in the relationship between institutional ownership and systemic risk. Prior studies suggest that disclosure plays an important role in decreasing information asymmetry, and may also increase liquidity and facilitate better monitoring. In the context of banks, Bushman and Williams (2015) find that higher quality financial reporting can mitigate systemic concerns. Moreover, as institutions experience adverse shocks in their portfolios, greater disclosure may reduce the uncertainty surrounding the fundamentals of the bank, reducing the propagation of the adverse shock for more transparent banks due to decreased correlation across investors' trades and trades within an investor's portfolio (e.g. Brunnermeier and Pedersen 2009). ${ }^{13}$ As a result, we predict that disclosure will moderate the relation between institutional ownership and systemic risk.

\footnotetext{
${ }^{13}$ Increased transparency reduces the uncertainty of a firm's true economic value, then this may reduce the propagation of systemic risk. For example, transparency will reduce information asymmetry and has the potential to improve liquidity by reducing private information concerns between investors; concerns that are more pronounced during market downturns, precisely when firms may prefer a lower cost of capital and the lack of liquidity is of most consequence. Analytically, Brunnermeier and Pedersen (2009), and Vayanos (2004), shows that when investors are hit with liquidity shocks, they will tend to liquidate and sell asset positions that they are most uncertain about ("flight to quality"). Therefore, to the extent that greater disclosures reduces the uncertainty of investors, then it has the potential to reduce the transmission of systemic risk for banks that are more transparent as institutional investors would be less inclined to sell those stocks in response to adverse movement in their portfolios and the need to fulfill potential redemptions.
} 
To test our above prediction, we partition our sample into banks with high and low levels of disclosure using two measures of bank disclosure predicated on the Basel III concept of more disclosure of information for market participants to utilize. First, we measure disclosure using management forecasts. Forecast equals one if the bank disclosed at least one management forecast over the prior year according to I/B/E/S Guidance. Second, we explore a measure of Disclosure Quantity, using the number of words in firm's 10-K scaled by 1000 . The idea is that longer filings contain a larger number of disclosed items and more information is available to investors.

Table 8 presents the results. Across both measures of disclosure, we find there is a significantly negative relationship between IO and $M E S$ and a significantly positive relationship between IO and Overlap_Low_Days for the low disclosure subsamples using both of our measures of disclosure. These results are all statistically significant at the $1 \%$ level. In contrast, for the high disclosure banks, there is a statistically insignificant coefficient on IO for MES and a significantly positive coefficient on IO for Overlap_Low_Days for both measures of disclosure. Furthermore, the statistically significant coefficients for the high disclosure firms are lower in magnitude than those of the low disclosure firms. Overall, these results are consistent with the notion that disclosure may play a role in mitigating the part IO plays in the propagation of systemic risk as the relationship between IO and systemic risk is largely isolated within low disclosure banks.

However, we must acknowledge that disclosure may have a direct effect on IO. For example, theoretical and empirical research suggests that institutional investors are attracted to firms with better disclosures due to lower monitoring costs (e.g. Healy et al. 1999; Bushee and Noe 2000; Lambert et al. 2007; Ferreira and Matos 2008). Given our arguments above that greater transparency may reduce systemic risk, one may expect to observe banks with high disclosure to have higher levels of IO and lower systemic risk, which may confound our disclosure tests. 
Notwithstanding, we are comfortable with our inference of a mediating effect of disclosure on the propagation of systemic risk by IO for the following reasons: (1) our consistent results that higher IO is associated with increases in systemic risk, (2) the measurement of IO and disclosure in $t-1$ and the inclusion of bank fixed effects, and (3) the empirical fact that within our sample, banks with higher disclosures have only marginally higher IO than those banks with low IO, we are comfortable that our disclosure results are identifying

\subsection{Exogenous changes in IO: Russell 1000/2000}

While we argue that IO plays a transmission role in the propagation of systemic risk in banks rather than inherently creating it, we note there may be a concern that IO may prefer certain bank types, in this case, banks exhibiting higher tail risk comovement. To empirically address this potential endogeneity concern, we adopt an instrumental variables approach. Specifically, we seek an instrument that is related to the level of IO, but uncorrelated with unobservable bank characteristics linked to systemic risk. We follow Appel et al. (2016) and use the inclusion of a bank in the top of the Russell 2000 index as opposed to the bottom of Russell 1000 index as an instrument. The argument is that around the index cutoff, banks should have similar characteristics, but the indexing strategies of institutional investors should be different enough to detect IO's propagation of systemic risk.

We restrict our sample from 2000 to 2006 and conduct our analyses using two bandwidths.

First, we follow Appel et al. (2016) and compare banks in the top 250 of Russell 2000 index to banks at the bottom 250 of Russell 1000 index. As few bank stocks are part of either index, our sample is reduced considerably. Thus, we also conduct our tests comparing banks in the top 750 of Russell 2000 index to banks at the bottom 750 of Russell 1000 index. 
Table 9 presents the results. Russell 2000 is an indicator variable equal to 1 if a bank is included in the top of the Russell 2000 index (ranked 1001 to 1250 or 1001 to 1750, depending on the bandwidth being used) and 0 if in the bottom of Russell 1000 index (ranked 751 to 1000 or 251 to 1000 , depending on the bandwidth being used) according to market capitalization weights calculated from CRSP. We first validate that the extent of IO is higher for banks included in the top of Russell 2000 index compared to banks at the bottom of Russell 1000 index, as indicated by the positive and significant coefficients for the Russell 2000 in the first stage regressions for both bandwidths presented in columns 1 and 4. Columns 2-3 and 5-6 replicate our main results using the predicted IO from this instrumental variable approach. Even in these much smaller subsamples, predicted IO is significantly associated with higher systemic risk in a consistent manner with our previous results.

\subsection{Sensitivity and Robustness Analyses}

We conduct several robustness tests to ensure our inferences remain valid. First, we reperform our main analysis using a MES measure based on the bottom $10 \%$ of equity market returns instead of $5 \%$. We find our main results are quantitatively and qualitatively similar and inferences remain unchanged. Second, our results are also robust to using equal-weighted market returns are opposed to value-weighted market returns for our systemic risk measures, as well as replacing the bank market beta with a total market beta. Finally, in addition to clustering by firm we also cluster by year and note that our results remain qualitatively similar.

\section{Conclusion}

In this paper we investigate whether institutional ownership in banking stocks is associated with increased tail risk comovement. Specifically, we examine whether IO acts as a transmission 
mechanism through which shocks in one bank are transmitted to other banks through overlapping investors and correlated trades. To examine our research question, we use a large sample of US banks from 2001-2013 and collect institutional ownership data for each bank. We then explore the relationship between institutional ownership and two different tail risk comovement measures. Our results provide robust evidence that banks with higher levels of institutional ownership have higher subsequent tail risk comovement. We also show that the result is more pronounced during economic downturns which is consistent with the view that during economic downturns the needs of banks to raise capital in conjunction with illiquid markets and IO's trading behavior are likely to make tail risk comovement more pronounced. We also find consistent cross-sectional evidence that IO increases tail-risk when banks have heightened capital needs and are most vulnerable.

Consistent with a trading mechanism, we find the results are stronger for active and transient IO, as well as for banks that have common ownership. However, we also find evidence that IO propagates systemic risk through non-overlapping ownership as well, consistent with investor clientele, style investing, and program trading theories.

We also find evidence that the adverse effects of IO are stronger for banks with more dispersed holdings, suggesting the results are particularly relevant when there are low incentives to monitor. Finally we find disclosure may play a role in mitigating the relationship between IO and future systemic risk; in particular, we find that the results are primarily isolated and stronger in low disclosure banks.

Overall our study makes two significant contributions to the literature. First, our paper contributes to the systemic risk literature by examining how the investor base of a bank can potentially facilitate systemic risk due to the network institutional holdings create that can thereby transmit systemic shocks through the banking sector. Our results suggest a specific mechanism 
through which the trading activity of institutional owners can in certain cases exacerbate systemic risk. In addition, we contribute to the literature examining the relation between disclosure and institutional owners. In contrast to the prior literature that suggests greater institutional ownership is a beneficial characteristic for firms, we posit and investigate a potential cost of increased institutional ownership by documenting that tail risk comovement is increasing in institutional ownership.

Our results also speak tangentially to the debate on the role of private monitoring in banks. The results suggest that while institutional investors may be able to act as a governance mechanism and promote private monitoring this needs to be weighed against the possibility that institutional ownership acts as a transmission mechanism for industry shocks. Since the financial crisis there has been a great deal of interest in understanding the nature of systemic risk in the financial sector and attempting to mitigate it through bank regulation and market discipline. Our paper offers evidence that while institutional owners can play a monitoring role in a bank and reduce risktaking incentives, these same institutions can actually become a catalyst for the very risk regulators hoped these investors would mitigate. 


\section{References}

ACHARYA, V.V.; L.H. PEDERSEN; T. PHILIPPON; AND M. RICHARDSON. "Measuring Systemic Risk" Review of Financial Studies, 30 (2017): 2-47.

ADRIAN, T.; AND M. BRUNNERMEIER. "CoVar" Federal Reserve Bank of New York Staff Reports Working Paper No. 348, (August 2009).

ANTON, M., AND C. POLK. “Connected Stocks” Journal of Finance, 69 (2014): 1099-1127.

APPEL, I.; T. GORMLEY; AND D. KEIM. "Passive investors, not passive owners" Journal of Financial Economics, 121 (2016): 111-141.

BANK FOR INTERNATIONAL SETTLEMENTS. "Revised Pillar 3 disclosure requirements." Basel Committee on Banking Supervision (2015). Available at: http://www.bis.org/bcbs/publ/d309.htm

BARBERIS, N., AND A. SHLEIFER. "Style Investing” Journal of Financial Economics, 68 (2003): 161-199.

BECK, T.; AND OLIVIER DE JONGHE. "Lending concentration, bank performance and systemic risk: exploring cross-country variation" The World Bank Policy Research Working Paper No. 6604, (September 2013).

BILliO, M.; M. GETMANSKY; A. LO; AND L. PELIZZON. "Econometric measures of connectedness and systemic risk in the finance and insurance sectors." University Ca'Foscari Venice and MIT Working Paper, (2011).

BISIAS, D.; M. FLOOD; A. LO; AND S. VALAVANIS. “A Survey of Systemic Risk Analytics.” Office of Financial Research, Working Paper 0001, (2012).

BOYSON, N.; C. STAHEL; AND R. STULZ. "Hedge Fund Contagion and Liquidity Shocks." Journal of Finance 65 (2010): 1789-1816.

BRUNNERMEIER, M.K., AND L.H. PEDERSEN. "Market liquidity and funding liquidity" Review of Financial Studies, 22 (2009): 2201-2238.

BUSHEE, B. "Do institutional investors prefer near-term earnings over long-run value?" Contemporary Accounting Research 18 (2001), 207-246.

BUSHEE, B., AND G. MILLER. "Investor Relations, Firm Visibility, and Investor Following." The Accounting Review 87 (2012): 867-897.

BUSHMAN, R.M., AND C.D. WILLIAMS “Accounting Discretion, Loan Loss Provisioning, and the discipline of Banks' risk-taking” Journal of Accounting \& Economics 54 (2012): 1-18. 
BUSHMAN, R.M., AND C.D. WILLIAMS. "Delayed Expected Loss Recognition and the Risk Profile of Banks.” Journal of Accounting Research 53 (2015): 511-554.

BUSHMAN R.M.; B.E. HENDRICKS; AND C.D. WILLIAMS. "Bank Competition: Measurement, Decision-Making, and Risk-Taking." Journal of Accounting Research 54 (2016): 777-826.

DELLA CROCE, R.; F. STEWART; AND J. YERMO. "Promoting longer-term investment by institutional investors: selected issues and policies" OECD Journal: Financial Market Trends (2011).

DE JONGHE, O. "Back to the basics in banking? A micro-analysis of banking system stability" Journal of Financial Intermediation 19 (2010): 387-417.

FINANCIAL STABILITY OVERSIGHT COUNCIL. "Implementation of the alternative investment fund managers directive" Financial Services Authority Consultation Paper CP 12/32 (November 2012) Available at: https://www.fca.org.uk/publication/consultation/cp12-32.pdf.

GREENWOOD, R.M., AND THESMAR, D. "Stock Price Fragility" Harvard Business School Working Paper No. 1490734, (March 2011). Available at: https://ssrn.com/abstract=1490734

INTERNATIONAL MONETARY FUND. “Global Financial Stability Report: Vulnerabilities, Legacies, and Policy Challenges.” (2015).

ISELIN, M.; S LIAO; AND H. ZHANG. "Common Block Ownership in Banks and Systemic Risk” Working Paper (December 2017).

KHAN, U. "Does Fair Value Accounting Contribute to Systemic Risk in the Banking Industry?" Contemporary Accounting Research," forthcoming.

KIRK, M., AND J. VINCENT. "Professional Investor Relations within the Firm." The Accounting Review 89 (2014): 1421-1452.

KNAUP, M.; AND W. WAGNER. "Forward-looking tail risk exposures at U.S. bank holding companies" Journal of Financial Services Research 42 (2012): 35-54.

KODRES, L.E., AND M. PRITSKER. “A Rational Expectations Model of Financial Contagion” Journal of Finance, 57 (2002): 769-799.

KORINEK, A. "Systemic Risk-Taking: Amplification Effects, Externalities, and Regulatory Responses" ECB Working Paper No. 1345, (May 2011). Available at SSRN: https://ssrn.com/abstract=1847483.

MANCONI, A.; M. MASSA; AND A. YASUDA. "The role of institutional investors in propagating the crisis of 2007-2008" Journal of Financial Economics 104 (2012): 491-518. 
OFFICE OF FINANCIAL RESEARCH. “Asset management and financial stability.” (2013).

PIERRET, D. "Systemic Risk and the Solvency-Liquidity Nexus of Banks." International Journal of Central Banking 11 (2015): 193-227.

PINDYCK, R.S., AND J.J. ROTEMBERG. "The Comovement of Stock Prices." The Quarterly Journal of Economics, 108 (1993): pp.1073-1104.

SHLEIFER, A., AND R. VISHY. "Large shareholders and corporate control." Journal of Political Economy 94 (1986): 461-488

SHLEIFER, A., AND R.VISHNY. "Liquidation Vales and Debt Capacity: A Market Equilibrium Approach” Journal of Finance, 47 (1992): 1343-1366.

SHLEIFER, A., AND R. VISHY. "A survey of corporate governance". Journal of Finance 52 (1997): 737-783.

SUN, Z. "Institutional Clientele and Comovement." Working Paper (May 15, 2015). Available at: https://ssrn.com/abstract=1332201.

VAYANOS, D. "Flight to quality, flight to liquidity, and the pricing of risk" NBER Working Paper No. 10327, (February 2004).

WAGNER, W. "Diversification at financial institutions and systemic crises" Journal of Financial Intermediation 19 (2010): 373-386.

YU, P. "The Value of Active Investing: Can Active Institutional Investors Remove Excess Comovement of Stock Returns? Journal of Financial and Quantitative Analysis, 47:3 (2012): 667-688. 


\section{Appendix 1 - Variable Descriptions}

\section{Systemic risk variables}

$M E S_{i, t}$

Overlap_Low_Days $s_{i, t}$
$=$ Marginal expected shortfall at the $5 \%$ level, defined as the average firm return on the lowest market return days as classified by the bottom $5 \%$ of annual value-weighted market return days during the current year

$=$ Number of days that overlap between the twenty lowest firm return days and the twenty lowest annual value-weighted market return days during the current year

\section{Institutional ownership variables}

$I O_{i, t-1}$

Active_IO $O_{i, t-1}$

Transient_IO $O_{i, t-1}$

Quasi-indexer_IO $O_{i, t-1}$

Dedicated_IO $O_{i, t-1}$

IO_Concentration $_{i, t-1}$

Russell $2000_{i, t-1}$
$=$ Institutional ownership holdings at the end of the prior year, defined as total shares held by institutions divided by the total shares outstanding

$=$ "Active" institutional holdings at the end of the prior year. We define active institutional owners based on portfolio turnover classifications provided by FactSet, where institutions classified as having "Very High" and "High" portfolio turnover are active

$=$ "Transient" institutional holdings at the end of the prior year. We define transient institutional owners based on classifications provided on Brian Bushee's website

$=$ "Quasi-indexer" institutional holdings at the end of the prior year. We define quasi-indexer institutional owners based on classifications provided on Brian Bushee's website

$=$ "Dedicated" institutional holdings at the end of the prior year. We define dedicated institutional owners based on classifications provided on Brian Bushee's website

= Concentration of institutional holdings using the HirschmanHerfindahl Index, normalized to be between zero and one. Institutional ownership is considered dispersed (concentrated) when the Hirschman-Herfindahl Index is below (above) the sample median.

$=$ Indicator variable equal to 1 if a bank is included in the top of the Russell 2000 index and 0 if in the bottom of Russell 1000 index according to market capitalization values calculated from CRSP. 


\section{Disclosure and control variables}

Forecast $_{i, t-1}$

Disclosure Quantity ${ }_{i, t-1}$

Size $_{i, t-1}$

Beta $_{i, t-1}$

Opacity $_{i, t-1}$

Tier $1_{i, t-1}$

Deposits $_{i, t-1}$

Revenue Mix ${ }_{i, t-1}$

Stock Volatility ${ }_{i, t-1}$

Recession $_{t}$

Private Debt to $G D P_{t}$

Capital Ratio $_{i, t}$

Liquid Asset Shortfall i,t
$=$ Indicator variable equal to 1 if the bank disclosed at least one management forecast over the prior year according to $\mathrm{I} / \mathrm{B} / \mathrm{E} / \mathrm{S}$ Guidance, and 0 otherwise

$=$ Number of words in firm's $10-\mathrm{K}$ scaled by 1000

$=\log$ of total assets at the end of the prior year

$=$ Correlation between annual value-weighted market return and firm return over the prior year

$=$ Amount of derivative liabilities scaled by total assets at the end of the prior year. The amount of derivatives liabilities is calculated as the sum of the gross amount of derivative liabilities from trading activities and that from non-trading (i.e., hedging) activities. The gross amount of derivative liabilities from non-trading activities is the sum of items bhck8745, bhck8746, bhck8747, and bhck8748 from FR Y-9C filings. The gross amount of derivative liabilities from trading activities is the sum of items bhckc220, bhckc222, bhck8737, bhck8738, bhck8739, and bhck8740

$=$ Tier 1 risk-adjusted capital ratio at the end of the prior year

$=$ Total deposits over total liabilities at the end of the prior year

$=$ Interest revenues over total revenues at the end of the prior year

$=$ Standard deviation of the firm's daily stock returns over the prior year

$=$ Indicator variable equal to 1 if the year is 2001, 2008 or 2009

$=$ U.S. Private sector debt to GDP. This ratio measures the indebtedness of non-financial corporations, households and nonprofit institutions serving households, as a percentage of GDP

$=$ Combined risk-adjusted capital ratio for the bank at the end of the year

$=$ Short-term debt minus short-term assets for the bank at the end of the year. Short-term debt is defined as Federal funds purchased + Repurchase agreements + Brokered deposits $(<\$ 100 \mathrm{~K}$, maturity $\leq 1$ Year $)+$ Time deposits $(\geq \$ 100 \mathrm{~K}$, maturity $\leq 1$ Year $)+$ Foreign office time deposits (maturity $\leq 1$ Year) + Commercial paper. Short-term assets are defined as Cash \& non-interest-bearing deposits + Total interest-bearing balances + Federal funds sold + Reverse repurchases agreements + Debt securities maturing or repriced (maturity $\leq 1$ Year) 


\section{Table 1: Descriptive Statistics}

This table reports sample descriptive statistics for our sample of banks with two-digit SIC codes beginning with 60 and 61 from 2001-2013. Variables are as defined in Appendix 1.

\begin{tabular}{|c|c|c|c|c|c|c|}
\hline Variables & Mean & Std Dev & Q1 & Median & Q3 & $\mathrm{N}$ \\
\hline$M E S$ & -0.0115 & 0.0160 & -0.0192 & -0.0083 & -0.0012 & 6,493 \\
\hline Overlap_Low_Days & 5.1314 & 3.7934 & 2.0000 & 4.0000 & 8.0000 & 6,493 \\
\hline$I O$ & 0.2644 & 0.2372 & 0.0733 & 0.1912 & 0.4131 & 6,493 \\
\hline Active_IO & 0.0050 & 0.0099 & 0.0000 & 0.0001 & 0.0057 & 6,493 \\
\hline Transient_IO & 0.0512 & 0.0691 & 0.0001 & 0.0196 & 0.0833 & 5,594 \\
\hline Quasi-indexer_IO & 0.1773 & 0.1842 & 0.0170 & 0.1146 & 0.2892 & 5,594 \\
\hline Dedicated_IO & 0.0251 & 0.0414 & 0.0000 & 0.0009 & 0.0372 & 5,594 \\
\hline IO_Concentration & 0.2257 & 0.2199 & 0.0694 & 0.1464 & 0.3049 & 6,493 \\
\hline Forecast & 0.1092 & 0.3118 & 0.0000 & 0.0000 & 0.0000 & 6,493 \\
\hline Disclosure Quantity & 3.8199 & 2.4064 & 2.5901 & 3.3693 & 4.47845 & 5,104 \\
\hline Size & 7.3175 & 1.4981 & 6.2830 & 7.0179 & 8.0300 & 6,493 \\
\hline Beta & 0.2884 & 0.2895 & 0.0485 & 0.1745 & 0.5531 & 6,493 \\
\hline Opacity & 0.0010 & 0.0052 & 0.0000 & 0.0000 & 0.0000 & 6,493 \\
\hline Tierl & 11.7361 & 3.5068 & 9.4100 & 11.2000 & 13.4000 & 6,493 \\
\hline Deposits & 0.8288 & 0.1091 & 0.7675 & 0.8491 & 0.9100 & 6,493 \\
\hline Revenue Mix & 0.8379 & 0.2965 & 0.7941 & 0.8606 & 0.9134 & 6,493 \\
\hline Stock Volatility & 0.0250 & 0.0128 & 0.0161 & 0.0211 & 0.0299 & 6,493 \\
\hline Private Debt to GDP & 199.0378 & 9.5627 & 188.5000 & 198.3000 & 204.7000 & 6,493 \\
\hline Capital Ratio & 14.6101 & 4.5624 & 11.8900 & 13.5000 & 15.8000 & 5,558 \\
\hline Liquid Asset Shortfall & $7,283.33$ & $46,808.08$ & 344.36 & 731.22 & $2,086.31$ & 6,167 \\
\hline
\end{tabular}




\section{Table 2: Systemic Risk and Institutional Ownership}

This table reports OLS regressions of our systemic risk measures on institutional ownership. All variables are as defined in Appendix 1. Institutional ownership and controls are lagged by one year. Bank and year fixed effects are included and standard errors are clustered by bank. Standard errors are reported below coefficient estimates. $* * * * *, *$ indicates significance at the $0.01,0.05$, and 0.10 level, respectively.

\begin{tabular}{lccc}
\hline \hline & \multicolumn{2}{c}{ Systemic Risk Proxy } \\
\cline { 2 - 4 } Variable & Prediction & $(1)$ & $(2)$ \\
\hline IO & $-/+$ & $-0.009 * * *$ & $2.803^{* * *}$ \\
Size & & $(0.002)$ & $(0.423)$ \\
Beta & $-0.003 * * *$ & $0.478^{* * *}$ \\
& $(0.001)$ & $(0.157)$ \\
Opacity & $-0.016^{* * *}$ & $4.524 * * *$ \\
& $(0.001)$ & $(0.263)$ \\
Tierl & -0.111 & 1.475 \\
& $(0.079)$ & $(18.482)$ \\
Deposits & -0.000 & $0.048^{* * *}$ \\
Revenue Mix & $(0.000)$ & $(0.015)$ \\
Stock Volatility & -0.005 & -0.176 \\
& $(0.004)$ & $(0.585)$ \\
Fixed Effects & 0.000 & -0.040 \\
Observations & $(0.000)$ & $(0.028)$ \\
R-squared & $-0.161 * * *$ & $-15.876^{* * *}$ \\
\hline
\end{tabular}




\section{Table 3: Systemic Risk and Institutional Ownership in Economic Downturns}

This table reports OLS regressions of our systemic risk measures on institutional ownership, partitioning the sample on expansion and recession periods and on Low Private Debt to GDP periods and High Private Debi to GDP periods. Panel A presents the results partitioning the sample into expansion and recession years. Recession years are 2001, 2008 and 2009. Panel B presents the results partitioning the sample into high and low private debt to GDP years. High Private Debt to GDP equals one when the U.S. Private Debt to GDP is above the sample median. Low Private Debt to GDP equals one when the U.S. Private Debt to GDP is below the sample median. Private debt to GDP is measured at the same year as MES and Overlap_Low_Days. High Private Debt to GDP years are 2005, 2006, 2007, 2008, 2009, 2010, 2011. All variables are as defined in Appendix 1. Institutional ownership and controls are lagged by one year. Bank and year fixed effects are included and standard errors are clustered by bank. Standard errors are reported below coefficient estimates. $* * *, * *, *$ indicates significance at the $0.01,0.05$, and 0.10 level, respectively.

Panel A: Partitions on Expansion and Recession Periods

\begin{tabular}{|c|c|c|c|c|}
\hline & \multicolumn{2}{|c|}{ Systemic Risk Proxy: MES } & \multicolumn{2}{|c|}{$\begin{array}{l}\text { Systemic Risk Proxy: } \\
\text { Overlap_Low Days }\end{array}$} \\
\hline & Expansion & Recession & Expansion & Recession \\
\hline Variable & (1) & (2) & (3) & (4) \\
\hline$I O$ & $\begin{array}{l}-0.008 * * * \\
(0.002)\end{array}$ & $\begin{array}{l}-0.012 \\
(0.009)\end{array}$ & $\begin{array}{l}2.365 * * * \\
(0.475)\end{array}$ & $\begin{array}{l}3.891^{* * *} \\
(1.266)\end{array}$ \\
\hline Size & $\begin{array}{l}-0.002 * * \\
(0.001)\end{array}$ & $\begin{array}{l}-0.007 * * * \\
(0.002)\end{array}$ & $\begin{array}{l}0.507 * * * \\
(0.188)\end{array}$ & $\begin{array}{l}0.829 * \\
(0.456)\end{array}$ \\
\hline Beta & $\begin{array}{l}-0.018 * * * \\
(0.002)\end{array}$ & $\begin{array}{l}-0.006 \\
(0.005)\end{array}$ & $\begin{array}{l}5.012 * * * \\
(0.325)\end{array}$ & $\begin{array}{l}4.314^{* * *} \\
(0.719)\end{array}$ \\
\hline Opacity & $\begin{array}{l}-0.046 \\
(0.053)\end{array}$ & $\begin{array}{l}-0.131 \\
(0.410)\end{array}$ & $\begin{array}{c}14.510 \\
(21.236)\end{array}$ & $\begin{array}{l}-61.254 * * \\
(30.753)\end{array}$ \\
\hline Tierl & $\begin{array}{l}-0.000 \\
(0.000)\end{array}$ & $\begin{array}{l}-0.000 \\
(0.000)\end{array}$ & $\begin{array}{l}0.054 * * * \\
(0.017)\end{array}$ & $\begin{array}{l}0.007 \\
(0.050)\end{array}$ \\
\hline Deposits & $\begin{array}{l}-0.008 * \\
(0.004)\end{array}$ & $\begin{array}{l}-0.003 \\
(0.012)\end{array}$ & $\begin{array}{l}-0.065 \\
(0.703)\end{array}$ & $\begin{array}{l}0.622 \\
(1.887)\end{array}$ \\
\hline Revenue Mix & $\begin{array}{l}-0.005 \\
(0.005)\end{array}$ & $\begin{array}{c}0.000 \\
(0.000)\end{array}$ & $\begin{array}{l}-0.318 \\
(0.777)\end{array}$ & $\begin{array}{l}-0.095 * * \\
(0.043)\end{array}$ \\
\hline Stock Volatility & $\begin{array}{l}-0.144^{* * *} \\
(0.032)\end{array}$ & $\begin{array}{l}-0.015 \\
(0.094)\end{array}$ & $\begin{array}{c}-12.194 * * \\
(5.825)\end{array}$ & $\begin{array}{l}-45.237 * * * \\
(12.536)\end{array}$ \\
\hline $\begin{array}{l}\text { Fixed Effects } \\
\text { Observations } \\
\text { R-squared }\end{array}$ & $\begin{array}{c}\text { Bank, Year } \\
4,930 \\
0.651\end{array}$ & $\begin{array}{c}\text { Bank, Year } \\
1,563 \\
0.763\end{array}$ & $\begin{array}{c}\text { Bank, Year } \\
4,930 \\
0.782\end{array}$ & $\begin{array}{c}\text { Bank, Year } \\
1,563 \\
0.887\end{array}$ \\
\hline
\end{tabular}


Table 3: Systemic Risk and Institutional Ownership in in Economic Downturns (continued)

Panel B: Partitions on Private Debt to GDP

\begin{tabular}{|c|c|c|c|c|}
\hline \multirow[b]{3}{*}{ Variable } & \multicolumn{2}{|c|}{ Systemic Risk Proxy: MES } & \multicolumn{2}{|c|}{$\begin{array}{l}\text { Systemic Risk Proxy: } \\
\text { Overlap_Low_Days }\end{array}$} \\
\hline & $\begin{array}{c}\text { Low Private Debt } \\
\text { to GDP }\end{array}$ & $\begin{array}{l}\text { High Private } \\
\text { Debt to GDP }\end{array}$ & $\begin{array}{l}\text { Low Private } \\
\text { Debt to GDP }\end{array}$ & $\begin{array}{l}\text { High Private } \\
\text { Debt to GDP }\end{array}$ \\
\hline & $(1)$ & $(2)$ & $(3)$ & $(4)$ \\
\hline IO & $\begin{array}{l}-0.008 * * * \\
(0.002)\end{array}$ & $\begin{array}{l}-0.014 * * * \\
(0.004)\end{array}$ & $\begin{array}{l}1.726 * * * \\
(0.619)\end{array}$ & $\begin{array}{l}4.522 * * * \\
(0.835)\end{array}$ \\
\hline Size & $\begin{array}{l}-0.002 * * \\
(0.001)\end{array}$ & $\begin{array}{l}-0.005^{* * *} \\
(0.002)\end{array}$ & $\begin{array}{l}0.686^{* * *} \\
(0.226)\end{array}$ & $\begin{array}{l}0.714 * * \\
(0.329)\end{array}$ \\
\hline Beta & $\begin{array}{l}-0.004 * * * \\
(0.002)\end{array}$ & $\begin{array}{l}-0.016^{* * * *} \\
(0.003)\end{array}$ & $\begin{array}{l}4.185^{* * * *} \\
(0.418)\end{array}$ & $\begin{array}{l}2.377 * * * \\
(0.493)\end{array}$ \\
\hline Opacity & $\begin{array}{c}0.119 \\
(0.122)\end{array}$ & $\begin{array}{l}-0.375 * * \\
(0.154)\end{array}$ & $\begin{array}{l}-23.641 \\
(35.517)\end{array}$ & $\begin{array}{c}27.212 \\
(21.593)\end{array}$ \\
\hline Tier 1 & $\begin{array}{l}-0.000 \\
(0.000)\end{array}$ & $\begin{array}{l}-0.000 \\
(0.000)\end{array}$ & $\begin{array}{c}0.040 * \\
(0.024)\end{array}$ & $\begin{array}{l}0.073 * * * \\
(0.025)\end{array}$ \\
\hline Deposits & $\begin{array}{c}0.003 \\
(0.004)\end{array}$ & $\begin{array}{l}-0.012 * \\
(0.007)\end{array}$ & $\begin{array}{l}-1.473 * \\
(0.872)\end{array}$ & $\begin{array}{r}2.034 * \\
(1.062)\end{array}$ \\
\hline Revenue Mix & $\begin{array}{l}-0.001 \\
(0.005)\end{array}$ & $\begin{array}{c}0.000 * \\
(0.000)\end{array}$ & $\begin{array}{l}-0.073 \\
(0.912)\end{array}$ & $\begin{array}{l}-0.045^{*} \\
(0.026)\end{array}$ \\
\hline Stock Volatility & $\begin{array}{l}-0.133 * * * \\
(0.032)\end{array}$ & $\begin{array}{l}-0.134^{* * * *} \\
(0.051)\end{array}$ & $\begin{array}{c}1.587 \\
(7.108)\end{array}$ & $\begin{array}{l}-35.122 * * * \\
(6.722)\end{array}$ \\
\hline $\begin{array}{l}\text { Fixed Effects } \\
\text { Observations } \\
\text { R-squared }\end{array}$ & $\begin{array}{c}\text { Bank, Year } \\
3,080 \\
0.679\end{array}$ & $\begin{array}{c}\text { Bank, Year } \\
3,415 \\
0.631\end{array}$ & $\begin{array}{c}\text { Bank, Year } \\
3,080 \\
0.804\end{array}$ & $\begin{array}{c}\text { Bank, Year } \\
3,415 \\
0.814\end{array}$ \\
\hline
\end{tabular}




\section{Table 4: Systemic Risk and Institutional Ownership for Banks with High and Low Capital Needs}

This table reports OLS regressions of our systemic risk measures on institutional ownership, partitioning the sample on banks' capital needs. Panel A presents the results partitioning the sample on banks' capital ratios. Low Capital Ratio equals one when the Combined Risk-Adjusted Capital Ratio for the bank is below 13\%. High Capital Ratio equals one when the Combined Risk-Adjusted Capital Ratio for the bank is above $20 \%$. Capital Ratios are measured at the same year as MES and Overlap_Low_Days. Panel B presents the results partitioning the sample on banks' Liquid Asset Shortfall. Low Liquid Asset Shortfall equals one when Liquid Asset Shortfall is in the bottom tercile. High Liquid Asset Shortfall equals one when Liquid Asset Shortfall is in the top tercile. Liquid Asset Shortfall is measured at the same year as MES and Overlap_Low_Days. All other variables are as defined in Appendix 1. Institutional ownership and controls are lagged by one year. Bank and year fixed effects are included and standard errors are clustered by bank. Standard errors are reported below coefficient estimates. $* * *, * *, *$ indicates significance at the $0.01,0.05$, and 0.10 level, respectively.

Panel A: Partitions on Capital Ratios

\begin{tabular}{|c|c|c|c|c|}
\hline \multirow[b]{3}{*}{ Variable } & \multicolumn{2}{|c|}{$M E S$} & \multicolumn{2}{|c|}{ Overlap_Low_Days } \\
\hline & $\begin{array}{l}\text { Low Capital Needs } \\
\text { (High Capital Ratio) }\end{array}$ & $\begin{array}{l}\text { High Capital Needs } \\
\text { (Low Capital Ratio) }\end{array}$ & $\begin{array}{l}\text { Low Capital Needs } \\
\text { (High Capital Ratio) }\end{array}$ & $\begin{array}{l}\text { High Capital Needs } \\
\text { (Low Capital Ratio) }\end{array}$ \\
\hline & (1) & $(2)$ & (3) & (4) \\
\hline Size & $\begin{array}{l}-0.001 \\
(0.003)\end{array}$ & $\begin{array}{l}-0.003^{*} \\
(0.002)\end{array}$ & $\begin{array}{c}0.553 \\
(1.386)\end{array}$ & $\begin{array}{c}0.367 \\
(0.309)\end{array}$ \\
\hline Opacity & $\begin{array}{c}0.240 \\
(0.545)\end{array}$ & $\begin{array}{l}-0.098 \\
(0.132)\end{array}$ & $\begin{array}{l}155.306^{*} \\
(82.523)\end{array}$ & $\begin{array}{c}45.027 \\
(30.790)\end{array}$ \\
\hline Deposits & $\begin{array}{c}0.013 \\
(0.015)\end{array}$ & $\begin{array}{l}-0.002 \\
(0.008)\end{array}$ & $\begin{array}{l}-2.013 \\
(3.126)\end{array}$ & $\begin{array}{c}2.024 * \\
(1.194)\end{array}$ \\
\hline Revenue Mix & $\begin{array}{l}-0.001 \\
(0.018)\end{array}$ & $\begin{array}{l}-0.006 \\
(0.010)\end{array}$ & $\begin{array}{l}-0.084 \\
(3.331)\end{array}$ & $\begin{array}{l}-0.176 \\
(1.326)\end{array}$ \\
\hline
\end{tabular}


Table 4: Systemic Risk and Institutional Ownership for Banks with High and Low Capital Needs (continued)

Panel B: Partitions on Liquid Asset Shortfall

\begin{tabular}{|c|c|c|c|c|}
\hline \multirow[b]{3}{*}{ Variable } & \multicolumn{2}{|c|}{$M E S$} & \multicolumn{2}{|c|}{ Overlap_Low_Days } \\
\hline & $\begin{array}{c}\text { Low Capital Needs } \\
\text { (Low Liquid Asset } \\
\text { Shortfall) }\end{array}$ & $\begin{array}{c}\text { High Capital Needs } \\
\text { (High Liquid Asset } \\
\text { Shortfall) }\end{array}$ & $\begin{array}{c}\text { Low Capital Needs } \\
\text { (Low Liquid Asset } \\
\text { Shortfall) }\end{array}$ & $\begin{array}{c}\text { High Capital Needs } \\
\text { (High Liquid Asset } \\
\text { Shortfall) }\end{array}$ \\
\hline & (1) & (2) & (3) & (4) \\
\hline$I O$ & $\begin{array}{l}-0.005 \\
(0.005)\end{array}$ & $\begin{array}{l}-0.007 * * \\
(0.003)\end{array}$ & $\begin{array}{c}0.909 \\
(1.135)\end{array}$ & $\begin{array}{l}1.588^{* * *} \\
(0.586)\end{array}$ \\
\hline Size & $\begin{array}{l}-0.001 \\
(0.002)\end{array}$ & $\begin{array}{l}-0.002 * \\
(0.001)\end{array}$ & $\begin{array}{c}0.055 \\
(0.261)\end{array}$ & $\begin{array}{c}0.233 \\
(0.250)\end{array}$ \\
\hline Beta & $\begin{array}{l}-0.001 \\
(0.004)\end{array}$ & $\begin{array}{l}-0.016^{* * *} \\
(0.003)\end{array}$ & $\begin{array}{c}0.259 \\
(0.681)\end{array}$ & $\begin{array}{l}5.846^{* * *} \\
(0.555)\end{array}$ \\
\hline Opacity & $\begin{array}{c}0.811 \\
(0.527)\end{array}$ & $\begin{array}{l}-0.111 \\
(0.094)\end{array}$ & $\begin{array}{c}-134.205^{* *} \\
(65.952)\end{array}$ & $\begin{array}{c}3.521 \\
(19.894)\end{array}$ \\
\hline Tier 1 & $\begin{array}{c}0.000 \\
(0.000)\end{array}$ & $\begin{array}{l}-0.000 \\
(0.000)\end{array}$ & $\begin{array}{c}0.037 * \\
(0.020)\end{array}$ & $\begin{array}{l}0.070 * * \\
(0.033)\end{array}$ \\
\hline Revenue Mix & $\begin{array}{c}0.000 \\
(0.005)\end{array}$ & $\begin{array}{l}-0.013 * * \\
(0.007)\end{array}$ & $\begin{array}{l}-0.022 \\
(0.704)\end{array}$ & $\begin{array}{l}-0.453 \\
(1.519)\end{array}$ \\
\hline Stock Volatility & $\begin{array}{l}-0.003 \\
(0.053)\end{array}$ & $\begin{array}{l}-0.339 * * * \\
(0.074)\end{array}$ & $\begin{array}{l}-0.365 \\
(6.372)\end{array}$ & $\begin{array}{l}-52.344 * * * \\
(10.771)\end{array}$ \\
\hline Fixed Effects & Bank, Year & Bank, Year & Bank, Year & Bank, Year \\
\hline Observations & 2,056 & 2,055 & 2,056 & 2,055 \\
\hline R-squared & 0.328 & 0.723 & 0.517 & 0.728 \\
\hline
\end{tabular}




\section{Table 5: Systemic Risk and the Type of Institutional Ownership}

This table reports OLS regressions of our systemic risk measures on the type of institutional ownership. Panel A presents the results for the active institutional ownership, ACTIVE_IO. $A C T I V E[I O$ represents the institutional ownership in the firm by active institutions based on fund turnover. Panel B presents the results for on transient, quasi-indexer and dedicated institutional ownership based on Bushee's (2001) classifications. All variables are as defined in Appendix 1. Institutional ownership and controls are lagged by one year. Bank and year fixed effects are included and standard errors are clustered by bank. Standard errors are reported below coefficient estimates. $* * *, * *, *$ indicates significance at the $0.01,0.05$, and 0.10 level, respectively.

Panel A: Active IO

\begin{tabular}{|c|c|c|c|}
\hline & & System & Proxy \\
\hline & & $M E S$ & Overlap_Low_Days \\
\hline Variable & Prediction & $(1)$ & $(2)$ \\
\hline Active_IO & $-/+$ & $\begin{array}{l}-0.047 * * \\
(0.020)\end{array}$ & $\begin{array}{l}10.787 * * * \\
(4.051)\end{array}$ \\
\hline Size & & $\begin{array}{l}-0.004 * * * \\
(0.001)\end{array}$ & $\begin{array}{l}0.700 * * * \\
(0.150)\end{array}$ \\
\hline Beta & & $\begin{array}{l}-0.017 * * * \\
(0.001)\end{array}$ & $\begin{array}{l}5.027 * * * \\
(0.243)\end{array}$ \\
\hline Opacity & & $\begin{array}{l}-0.121 \\
(0.081)\end{array}$ & $\begin{array}{c}5.359 \\
(17.630)\end{array}$ \\
\hline Tierl & & $\begin{array}{l}-0.000 * * \\
(0.000)\end{array}$ & $\begin{array}{l}0.072 * * * \\
(0.015)\end{array}$ \\
\hline Deposits & & $\begin{array}{l}-0.005 \\
(0.004)\end{array}$ & $\begin{array}{l}-0.073 \\
(0.591)\end{array}$ \\
\hline Revenue Mix & & $\begin{array}{c}0.000 * \\
(0.000)\end{array}$ & $\begin{array}{l}-0.056^{* *} \\
(0.028)\end{array}$ \\
\hline Stock Volatility & & $\begin{array}{l}-0.145 * * * \\
(0.029)\end{array}$ & $\begin{array}{c}-20.948 * * * \\
(4.418)\end{array}$ \\
\hline $\begin{array}{l}\text { Fixed Effects } \\
\text { Observations } \\
\text { R-squared }\end{array}$ & & $\begin{array}{c}\text { Bank, Year } \\
6,493 \\
0.607\end{array}$ & $\begin{array}{c}\text { Bank, Year } \\
6,493 \\
0.778\end{array}$ \\
\hline
\end{tabular}


Table 5: Systemic Risk and the Type of Institutional Ownership (continued)

Panel B: Transient, Quasi-Indexer and Dedicated IO

\begin{tabular}{|c|c|c|c|c|c|c|c|c|c|}
\hline \multirow[b]{2}{*}{ Variable } & \multirow[b]{2}{*}{ Pred. } & \multicolumn{4}{|c|}{ Systemic Risk Proxy: MES } & \multicolumn{4}{|c|}{ Systemic Risk Proxy: Overlap_Low_Days } \\
\hline & & (1) & $(2)$ & (3) & (4) & $(5)$ & (6) & (7) & $(8)$ \\
\hline \multirow[t]{2}{*}{ Transient_IO } & - & $-0.026 * * *$ & & & $-0.017 * * *$ & $6.328 * * *$ & & & $4.537 * * *$ \\
\hline & & $(0.005)$ & & & $(0.005)$ & $(0.967)$ & & & $(1.031)$ \\
\hline \multirow[t]{2}{*}{ Quasi-indexer_IO } & - & & $-0.016 * * *$ & & $-0.012 * * *$ & & $3.350 * * *$ & & $2.299 * * *$ \\
\hline & & & $(0.003)$ & & $(0.003)$ & & $(0.605)$ & & $(0.656)$ \\
\hline \multirow[t]{2}{*}{ Dedicated_IO } & + & & & 0.004 & 0.011 & & & -1.432 & $-3.010 * *$ \\
\hline & & & & $(0.007)$ & $(0.007)$ & & & $(1.385)$ & $(1.402)$ \\
\hline \multirow[t]{2}{*}{ Size } & & $-0.004 * * *$ & $-0.004 * * *$ & $-0.005 * * *$ & $-0.004 * * *$ & $0.786 * * *$ & $0.663 * * *$ & $0.869 * * *$ & $0.713 * * *$ \\
\hline & & $(0.001)$ & $(0.001)$ & $(0.001)$ & $(0.001)$ & $(0.164)$ & $(0.166)$ & $(0.168)$ & $(0.165)$ \\
\hline \multirow[t]{2}{*}{ Beta } & & $-0.016 * * *$ & $-0.016 * * *$ & $-0.017 * * *$ & $-0.015 * * *$ & $4.873 * * *$ & $4.823 * * *$ & $5.135 * * *$ & $4.677 * * *$ \\
\hline & & $(0.001)$ & $(0.001)$ & $(0.001)$ & $(0.001)$ & $(0.264)$ & $(0.272)$ & $(0.260)$ & $(0.274)$ \\
\hline \multirow[t]{2}{*}{ Opacity } & & -0.154 & -0.164 & $-0.184^{*}$ & -0.141 & 4.574 & 7.644 & 11.603 & 1.453 \\
\hline & & $(0.102)$ & $(0.106)$ & $(0.110)$ & $(0.103)$ & $(18.172)$ & $(18.351)$ & $(16.695)$ & $(19.514)$ \\
\hline \multirow[t]{2}{*}{ Tier 1} & & -0.000 & -0.000 & $-0.000 * *$ & -0.000 & $0.067 * * *$ & $0.068 * * *$ & $0.085 * * *$ & $0.064 * * *$ \\
\hline & & $(0.000)$ & $(0.000)$ & $(0.000)$ & $(0.000)$ & $(0.017)$ & $(0.017)$ & $(0.017)$ & $(0.017)$ \\
\hline \multirow[t]{2}{*}{ Deposits } & & $-0.006^{*}$ & $-0.007 *$ & $-0.007^{*}$ & $-0.007 *$ & 0.411 & 0.577 & 0.488 & 0.521 \\
\hline & & $(0.004)$ & $(0.004)$ & $(0.004)$ & $(0.004)$ & $(0.654)$ & $(0.655)$ & $(0.661)$ & $(0.655)$ \\
\hline \multirow[t]{2}{*}{ Revenue Mix } & & $0.000 *$ & $0.000 *$ & $0.000 * *$ & $0.000 *$ & $-0.044 *$ & $-0.051 *$ & $-0.057 * *$ & $-0.049 *$ \\
\hline & & $(0.000)$ & $(0.000)$ & $(0.000)$ & $(0.000)$ & $(0.026)$ & $(0.026)$ & $(0.027)$ & $(0.026)$ \\
\hline \multirow[t]{2}{*}{ Stock Volatility } & & $-0.130 * * *$ & $-0.131 * * *$ & $-0.120 * * *$ & $-0.135 * * *$ & $-25.318 * * *$ & $-25.444 * * *$ & $-27.775 * * *$ & $-24.191 * * *$ \\
\hline & & $(0.030)$ & $(0.030)$ & $(0.030)$ & $(0.030)$ & $(5.070)$ & $(5.147)$ & $(5.134)$ & $(5.098)$ \\
\hline Fixed Effects & & Bank, Year & Bank, Year & Bank, Year & Bank, Year & Bank, Year & Bank, Year & Bank, Year & Bank, Year \\
\hline Observations & & 5,594 & 5,594 & 5,594 & 5,594 & 5,594 & 5,594 & 5,594 & 5,594 \\
\hline R-squared & & 0.639 & 0.639 & 0.635 & 0.640 & 0.789 & 0.789 & 0.787 & 0.791 \\
\hline
\end{tabular}




\section{Table 6: Common Overlap in Institutional Ownership}

This table reports OLS regressions of our systemic risk measures on institutional ownership, $I O$, and control variables. We match each bank-year to (1) banks that share common institutional ownership (Common Overlap) and (2) banks that do not share common institutional ownership. We then repeat our analysis from Table 2 across the two sets of matched banks to examine whether common overlap in IO contributes to systemic risk. Panel A presents results for $M E S$ as our dependent variable, while Panel B presents results for Overlap_Low_Days dependent variable. All variables are as defined in Appendix 1. Institutional ownership and controls are lagged by one year. Bank and year fixed effects are included and standard errors are clustered by bank. Standard errors are reported below coefficient estimates. ***, **, * indicates significance at the $0.01,0.05$, and 0.10 level, respectively.

Panel A: MES

\begin{tabular}{|c|c|c|c|}
\hline & & \multicolumn{2}{|c|}{ Systemic Risk Proxy: MES } \\
\hline & & Common Overlap & Non-common \\
\hline Variable & Prediction & (1) & (2) \\
\hline$I O$ & - & $\begin{array}{l}-0.028 * * * \\
(0.008)\end{array}$ & $\begin{array}{l}-0.006 * * * \\
(0.002)\end{array}$ \\
\hline Size & & $\begin{array}{l}0.234 * * * \\
(0.023)\end{array}$ & $\begin{array}{l}0.328 * * * \\
(0.013)\end{array}$ \\
\hline Beta & & $\begin{array}{l}-0.003 * * * \\
(0.001)\end{array}$ & $\begin{array}{l}-0.001 * * * \\
(0.000)\end{array}$ \\
\hline Opacity & & $\begin{array}{l}-0.199 * * \\
(0.081)\end{array}$ & $\begin{array}{l}-0.126^{* * * *} \\
(0.051)\end{array}$ \\
\hline Tier1 & & $\begin{array}{l}-0.001^{* *} \\
(0.000)\end{array}$ & $\begin{array}{l}-0.001 * * \\
(0.000)\end{array}$ \\
\hline Deposits & & $\begin{array}{l}-0.002 \\
(0.003)\end{array}$ & $\begin{array}{l}-0.003 * \\
(0.002)\end{array}$ \\
\hline Revenue Mix & & $\begin{array}{l}-0.000 \\
(0.000)\end{array}$ & $\begin{array}{l}-0.002 \\
(0.002)\end{array}$ \\
\hline Stock Volatility & & $\begin{array}{l}-0.162 * * * \\
(0.014)\end{array}$ & $\begin{array}{l}-0.224 * * * \\
(0.019)\end{array}$ \\
\hline Fixed Effects & & Bank, Year & Bank, Year \\
\hline Observations & & 6,490 & 6,490 \\
\hline R-squared & & 0.725 & 0.703 \\
\hline
\end{tabular}




\section{Table 6: Common Overlap in Institutional Ownership (continued)}

Panel B: Overlap_Low_Days

\begin{tabular}{|c|c|c|c|}
\hline & & \multicolumn{2}{|c|}{ Systemic Risk Proxy: Overlap_Low_Days } \\
\hline & & Common Overlap & Non-common \\
\hline Variable & Prediction & (1) & (2) \\
\hline IO & + & $\begin{array}{l}6.923 * * * \\
(2.132)\end{array}$ & $\begin{array}{l}1.743 * * * \\
(0.428)\end{array}$ \\
\hline Size & & $\begin{array}{l}0.805 * * * \\
(0.108)\end{array}$ & $\begin{array}{l}0.691 * * * \\
(0.131)\end{array}$ \\
\hline Beta & & $\begin{array}{l}5.126^{* * *} \\
(0.294)\end{array}$ & $\begin{array}{l}5.959 * * * \\
(0.314)\end{array}$ \\
\hline Opacity & & $\begin{array}{l}10.672 \\
(7.994)\end{array}$ & $\begin{array}{c}14.619 \\
(12.463)\end{array}$ \\
\hline Tier1 & & $\begin{array}{l}0.089 * * * \\
(0.011)\end{array}$ & $\begin{array}{l}0.100 * * * \\
(0.069)\end{array}$ \\
\hline Deposits & & $\begin{array}{l}-0.153 \\
(0.201)\end{array}$ & $\begin{array}{l}-0.237 \\
(0.591)\end{array}$ \\
\hline Revenue Mix & & $\begin{array}{l}-0.076 * \\
(0.039)\end{array}$ & $\begin{array}{l}-0.094 \\
(0.081)\end{array}$ \\
\hline Stock Volatility & & $\begin{array}{c}-19.526 * * * \\
(6.165)\end{array}$ & $\begin{array}{c}-24.042 * * * \\
(5.386)\end{array}$ \\
\hline $\begin{array}{l}\text { Fixed Effects } \\
\text { Observations } \\
\text { R-squared }\end{array}$ & & $\begin{array}{c}\text { Bank, Year } \\
6,490 \\
0.792\end{array}$ & $\begin{array}{c}\text { Bank, Year } \\
6,490 \\
0.749\end{array}$ \\
\hline
\end{tabular}




\section{Table 7: Systemic Risk and Institutional Ownership Dispersion}

This table reports OLS regressions of our systemic risk measures on institutional ownership, partitioning the sample on the median of IO_Concentration. All variables are as defined in Appendix 1. Institutional ownership and controls are lagged by one year. Bank and year fixed effects are included and standard errors are clustered by bank. Standard errors are reported below coefficient estimates. $* * *, * *, *$ indicates significance at the $0.01,0.05$, and 0.10 level, respectively.

\begin{tabular}{|c|c|c|c|c|c|}
\hline & & \multicolumn{2}{|c|}{ Systemic Risk Proxy: MES } & \multicolumn{2}{|c|}{ Systemic Risk Proxy: Overlap_Low_Days } \\
\hline & & $\begin{array}{c}\text { Concentrated } \\
\text { Ownership }\end{array}$ & $\begin{array}{l}\text { Dispersed } \\
\text { Ownership }\end{array}$ & $\begin{array}{c}\text { Concentrated } \\
\text { Ownership }\end{array}$ & $\begin{array}{l}\text { Dispersed } \\
\text { Ownership }\end{array}$ \\
\hline Variable & Prediction & $(1)$ & $(2)$ & (3) & (4) \\
\hline$I O$ & & $(0.004)$ & $(0.003)$ & $(0.768)$ & $(0.546)$ \\
\hline Size & & $-0.003 * *$ & -0.002 & 0.339 & 0.297 \\
\hline Beta & & $(0.003)$ & $(0.002)$ & $(0.539)$ & $(0.408)$ \\
\hline \multirow[t]{2}{*}{ Opacity } & & $-0.415^{*}$ & -0.060 & $94.491 * * *$ & -5.046 \\
\hline & & $(0.217)$ & $(0.090)$ & $(31.296)$ & $(22.397)$ \\
\hline \multirow[t]{2}{*}{ Tierl } & & -0.000 & 0.000 & $0.050 * *$ & 0.036 \\
\hline & & $(0.000)$ & $(0.000)$ & $(0.019)$ & $(0.025)$ \\
\hline \multirow[t]{2}{*}{ Stock Volatility } & & -0.013 & $-0.302 * * *$ & -0.900 & $-39.632 * * *$ \\
\hline & & $(0.041)$ & $(0.052)$ & $(5.433)$ & $(9.589)$ \\
\hline Fixed Effects & & Bank, Year & Bank, Year & Bank, Year & Bank, Year \\
\hline Observations & & 3,053 & 3,054 & 3,053 & 3,054 \\
\hline R-squared & & 0.381 & 0.701 & 0.525 & 0.760 \\
\hline
\end{tabular}




\section{Table 8: Systemic Risk, Institutional Ownership and Disclosure}

This table reports OLS regressions of our systemic risk measures on institutional ownership partitioning on bank's level of disclosure. Forecast equals to one when the bank disclosed at least one management forecast over the year. Disclosure Quantity is high when the length of 10-K disclosures is above the sample median. All variables are as defined in Appendix 1. Institutional ownership and controls are lagged by one year. Bank and year fixed effects are included and standard errors are clustered by bank. Standard errors are reported below coefficient estimates. $* * *, * * *$ indicates significance at the $0.01,0.05$, and 0.10 level, respectively.

Panel A: Partitions on Management Forecasts

\begin{tabular}{|c|c|c|c|c|}
\hline \multirow[b]{3}{*}{ Variable } & \multicolumn{2}{|c|}{$M E S$} & \multicolumn{2}{|c|}{ Overlap_Low_Days } \\
\hline & $\begin{array}{l}\text { Low Disclosure } \\
\text { (No Forecast) }\end{array}$ & $\begin{array}{l}\text { High Disclosure } \\
\text { (Forecast) }\end{array}$ & $\begin{array}{l}\text { Low Disclosure } \\
\text { (No Forecast) }\end{array}$ & $\begin{array}{l}\text { High Disclosure } \\
\text { (Forecast) }\end{array}$ \\
\hline & $(1)$ & $(2)$ & $(3)$ & $(4)$ \\
\hline \multirow[t]{2}{*}{$I O$} & $-0.007 * * *$ & -0.008 & $3.053 * * *$ & $2.435^{*}$ \\
\hline & $(0.002)$ & $(0.006)$ & $(0.469)$ & $(1.464)$ \\
\hline \multirow[t]{2}{*}{ Size } & $-0.003 * * *$ & -0.000 & $0.354 * *$ & $1.198 * *$ \\
\hline & $(0.001)$ & $(0.002)$ & $(0.178)$ & $(0.536)$ \\
\hline \multirow[t]{2}{*}{ Beta } & $-0.016 * * *$ & -0.008 & $4.324 * * *$ & $5.453 * * *$ \\
\hline & $(0.001)$ & $(0.006)$ & $(0.281)$ & $(1.151)$ \\
\hline \multirow[t]{2}{*}{ Opacity } & $-0.221 *$ & -0.001 & 23.012 & -43.279 \\
\hline & $(0.131)$ & $(0.172)$ & $(18.038)$ & $(41.468)$ \\
\hline \multirow{2}{*}{ Tier 1} & -0.000 & -0.000 & $0.040 * *$ & 0.110 \\
\hline & $(0.000)$ & $(0.000)$ & $(0.016)$ & $(0.082)$ \\
\hline \multirow[t]{2}{*}{ Deposits } & -0.006 & 0.015 & -0.303 & 0.556 \\
\hline & $(0.004)$ & $(0.012)$ & $(0.616)$ & $(2.631)$ \\
\hline \multirow[t]{2}{*}{ Revenue Mix } & $0.000 * * *$ & $-0.022 *$ & -0.023 & -2.897 \\
\hline & $(0.000)$ & $(0.012)$ & $(0.024)$ & $(2.930)$ \\
\hline \multirow[t]{2}{*}{ Stock Volatility } & $-0.135 * * *$ & $-0.293^{*}$ & $-15.713 * * *$ & -31.374 \\
\hline & $(0.031)$ & $(0.157)$ & $(4.622)$ & $(30.183)$ \\
\hline Fixed Effects & Bank, Year & Bank, Year & Bank, Year & Bank, Year \\
\hline Observations & 5,786 & 709 & 5,786 & 709 \\
\hline R-squared & 0.593 & 0.827 & 0.768 & 0.828 \\
\hline
\end{tabular}


Table 8: Systemic Risk, Institutional Ownership and Disclosure (continued)

Panel B: Partitions on Disclosure Quantity

\begin{tabular}{|c|c|c|c|c|}
\hline \multirow[b]{3}{*}{ Variable } & \multicolumn{2}{|c|}{$M E S$} & \multicolumn{2}{|c|}{ Overlap_Low_Days } \\
\hline & $\begin{array}{c}\text { Low Disclosure } \\
\text { (Below Median } \\
\text { Disclosure Quantity) }\end{array}$ & $\begin{array}{c}\text { High Disclosure } \\
\text { (Above Median } \\
\text { Disclosure Quantity) }\end{array}$ & $\begin{array}{c}\text { Low Disclosure } \\
\text { (Below Median } \\
\text { Disclosure Quantity) }\end{array}$ & $\begin{array}{c}\text { High Disclosure } \\
\text { (Above Median } \\
\text { Disclosure Quantity) }\end{array}$ \\
\hline & (1) & (2) & (3) & (4) \\
\hline$I O$ & $\begin{array}{l}-0.018 * * * \\
(0.005)\end{array}$ & $\begin{array}{l}-0.002 \\
(0.004)\end{array}$ & $\begin{array}{l}3.723 * * * \\
(0.968)\end{array}$ & $\begin{array}{l}1.628 * * \\
(0.714)\end{array}$ \\
\hline Size & $\begin{array}{l}-0.005^{* * *} \\
(0.002)\end{array}$ & $\begin{array}{l}-0.005^{* * *} \\
(0.002)\end{array}$ & $\begin{array}{c}0.489 \\
(0.308)\end{array}$ & $\begin{array}{l}1.120^{* * *} \\
(0.322)\end{array}$ \\
\hline Beta & $\begin{array}{l}-0.011 \text { *** } \\
(0.002)\end{array}$ & $\begin{array}{l}-0.014^{* * * *} \\
(0.003)\end{array}$ & $\begin{array}{l}3.794 * * * \\
(0.492)\end{array}$ & $\begin{array}{l}2.688^{* * * *} \\
(0.579)\end{array}$ \\
\hline Opacity & $\begin{array}{l}-0.238 \\
(0.251)\end{array}$ & $\begin{array}{l}-0.108 \\
(0.112)\end{array}$ & $\begin{array}{l}-18.570 \\
(43.872)\end{array}$ & $\begin{array}{l}17.613 \\
(20.758)\end{array}$ \\
\hline Tier 1 & $\begin{array}{c}0.000 \\
(0.000)\end{array}$ & $\begin{array}{l}-0.000 \\
(0.000)\end{array}$ & $\begin{array}{c}0.051 \\
(0.031)\end{array}$ & $\begin{array}{l}0.094^{* * *} \\
(0.031)\end{array}$ \\
\hline Deposits & $\begin{array}{l}-0.011 \\
(0.007)\end{array}$ & $\begin{array}{c}0.006 \\
(0.007)\end{array}$ & $\begin{array}{c}0.315 \\
(1.079)\end{array}$ & $\begin{array}{l}-0.036 \\
(1.243)\end{array}$ \\
\hline Revenue Mix & $\begin{array}{l}0.000^{* * * *} \\
(0.000)\end{array}$ & $\begin{array}{l}-0.003 \\
(0.005)\end{array}$ & $\begin{array}{l}-0.047 * * \\
(0.020)\end{array}$ & $\begin{array}{l}-1.389 * * \\
(0.542)\end{array}$ \\
\hline Stock Volatility & $\begin{array}{l}-0.119 * \\
(0.064)\end{array}$ & $\begin{array}{l}-0.125^{* *} \\
(0.050)\end{array}$ & $\begin{array}{l}-5.636 \\
(8.937)\end{array}$ & $\begin{array}{c}-25.555^{* * *} \\
(8.156)\end{array}$ \\
\hline Fixed Effects & Bank, Year & Bank, Year & Bank, Year & Bank, Year \\
\hline Observations & 2,552 & 2,552 & 2,552 & 2,552 \\
\hline R-squared & 0.600 & 0.708 & 0.735 & 0.814 \\
\hline
\end{tabular}




\section{Table 9: Instrumental Variable Regressions}

This table reports OLS regressions of our systemic risk measures on institutional ownership using an instrumental variable approach. Russell 2000 is an indicator variable equal to 1 if a bank is included in the top of the Russell 2000 index (ranked 1001 to 1250 or 1001 to 1750 , depending on the bandwidth being used) and 0 if in the bottom of Russell 1000 index (ranked 751 to 1000 or 251 to 1000, depending on the bandwidth being used) according to market capitalization weights calculated from CRSP. The sample period is from 2000 to 2006. All variables are as defined in Appendix 1. Institutional ownership and controls are lagged by one year. Standard errors are clustered by bank. Standard errors are reported below coefficient estimates. $* * * * *, *$ indicates significance at the $0.01,0.05$, and 0.10 level, respectively.

\begin{tabular}{|c|c|c|c|c|c|c|c|}
\hline & & \multicolumn{3}{|c|}{ Bandwidth: 250} & \multicolumn{3}{|c|}{ Bandwidth: 750} \\
\hline & & $I O$ & $M E S$ & Overlap Low Days & $I O$ & $M E S$ & Overlap Low Days \\
\hline Variable & Prediction & (1) & $(2)$ & $(3)$ & (4) & $(5)$ & $(6)$ \\
\hline Russell 2000 & + & $\begin{array}{l}0.080 * * \\
(0.036)\end{array}$ & & & $\begin{array}{l}0.095 * * \\
(0.037)\end{array}$ & & \\
\hline$\widehat{I O}$ & $-/+/-/+$ & & $\begin{array}{l}-0.084 * * \\
(0.040)\end{array}$ & $\begin{array}{l}10.446^{*} \\
(6.263)\end{array}$ & & $\begin{array}{r}-0.079 * * \\
(0.031)\end{array}$ & $\begin{array}{c}7.394 * \\
(4.177)\end{array}$ \\
\hline Size & & $\begin{array}{l}-0.106 \\
(0.069)\end{array}$ & $\begin{array}{l}-0.010 \\
(0.008)\end{array}$ & $\begin{array}{c}1.250 \\
(1.173)\end{array}$ & $\begin{array}{l}-0.101 * * \\
(0.050)\end{array}$ & $\begin{array}{l}-0.008 \\
(0.005)\end{array}$ & $\begin{array}{c}0.963 \\
(0.663)\end{array}$ \\
\hline Beta & & $\begin{array}{l}0.230 * * \\
(0.105)\end{array}$ & $\begin{array}{l}0.026^{* *} \\
(0.012)\end{array}$ & $\begin{array}{c}1.878 \\
(1.984)\end{array}$ & $\begin{array}{c}0.145^{*} \\
(0.082)\end{array}$ & $\begin{array}{c}0.011 \\
(0.008)\end{array}$ & $\begin{array}{l}3.994 * * * \\
(1.073)\end{array}$ \\
\hline Opacity & & $\begin{array}{c}7.169 \\
(11.383)\end{array}$ & $\begin{array}{c}0.470 \\
(0.985)\end{array}$ & $\begin{array}{l}-134.323 \\
(142.669)\end{array}$ & $\begin{array}{c}0.214 \\
(4.371)\end{array}$ & $\begin{array}{l}-0.052 \\
(0.372)\end{array}$ & $\begin{array}{c}17.050 \\
(59.063)\end{array}$ \\
\hline Tier 1 & & $\begin{array}{l}-0.011 \\
(0.009)\end{array}$ & $\begin{array}{l}-0.001 \\
(0.001)\end{array}$ & $\begin{array}{l}-0.032 \\
(0.135)\end{array}$ & $\begin{array}{l}-0.010 \\
(0.007)\end{array}$ & $\begin{array}{l}-0.001 \\
(0.001)\end{array}$ & $\begin{array}{c}0.048 \\
(0.073)\end{array}$ \\
\hline Deposits & & $\begin{array}{c}0.046 \\
(0.212)\end{array}$ & $\begin{array}{c}0.006 \\
(0.016)\end{array}$ & $\begin{array}{c}1.141 \\
(2.231)\end{array}$ & $\begin{array}{l}-0.106 \\
(0.205)\end{array}$ & $\begin{array}{l}-0.009 \\
(0.015)\end{array}$ & $\begin{array}{c}2.730 \\
(1.665)\end{array}$ \\
\hline Revenue Mix & & $\begin{array}{l}-0.402 \\
(0.250)\end{array}$ & $\begin{array}{l}-0.034 \\
(0.027)\end{array}$ & $\begin{array}{c}4.170 \\
(3.835)\end{array}$ & $\begin{array}{l}-0.274 \\
(0.166)\end{array}$ & $\begin{array}{r}-0.036^{* *} \\
(0.016)\end{array}$ & $\begin{array}{l}4.427 * * * \\
(1.699)\end{array}$ \\
\hline Stock Volatility & & $\begin{array}{l}5.582 * * \\
(2.227)\end{array}$ & $\begin{array}{c}0.194 \\
(0.273)\end{array}$ & $\begin{array}{c}-8.650 \\
(41.175)\end{array}$ & $\begin{array}{c}0.008 \\
(2.334)\end{array}$ & $\begin{array}{l}-0.114 \\
(0.159)\end{array}$ & $\begin{array}{c}18.356 \\
(20.740)\end{array}$ \\
\hline Log Market Value & & $\begin{array}{l}0.233 * * * \\
(0.051)\end{array}$ & $\begin{array}{c}0.011 \\
(0.009)\end{array}$ & $\begin{array}{l}-0.327 \\
(1.518)\end{array}$ & $\begin{array}{l}0.147 * * * \\
(0.045)\end{array}$ & $\begin{array}{c}0.006 \\
(0.005)\end{array}$ & $\begin{array}{c}0.496 \\
(0.644)\end{array}$ \\
\hline Observations & & 215 & 215 & 215 & 676 & 676 & 676 \\
\hline R-squared & & 0.237 & & & 0.119 & & \\
\hline
\end{tabular}

